\title{
Results of LA-ICP-MS sulfide mapping from Algoma-type BIF gold systems with implications for the nature of mineralizing fluids, metal sources, and deposit models
}

\author{
B. Gourcerol ${ }^{1,2}$ - D. J. Kontak ${ }^{1}$ • P. C. Thurston ${ }^{1}$ • J. A. Petrus ${ }^{1}$
}

Received: 29 July 2016 / Accepted: 13 December 2017

(C) Springer-Verlag GmbH Germany, part of Springer Nature 2018

\begin{abstract}
Quantitative laser ablation inductively coupled plasma-mass spectrometry (LA-ICP-MS) element distribution maps combined with traverse mode analyses have been acquired on various sulfides (pyrite, pyrrhotite, arsenopyrite) from three Canadian Algoma-type BIF-hosted gold deposits $(\sim 4 \mathrm{Moz} \mathrm{Au}$ Meadowbank, $\geq 2.8 \mathrm{Moz}$ Au Meliadine district, $\sim 6 \mathrm{Moz} \mathrm{Au}$ Musselwhite). These data, in conjunction with detailed petrographic and SEM-EDS observations, provide insight into the nature and relative timing of gold events, the presence and implication of trace element zoning regarding crystallization processes, and elemental associations that fingerprint gold events. Furthermore, the use of an innovative method of processing the LA-ICP-MS data in map and traverse modes, whereby the results are fragmented into time-slice data, to generate various binary plots ( $\mathrm{Ag}$ versus $\mathrm{Ni}$ ) provides a means to identify elemental associations (Te, Bi) not otherwise apparent. This integrated means of treating geochemical data, along with petrography, allows multiple gold events and remobilization processes to be recognized and their elemental associations determined. The main gold event in each of these deposits is characterized by the coupling of an As-Se-TeAg element association coincident with intense stratabound sulfide-replacement of the Fe-rich host rock. Additionally, the data the presence of a later remobilization event, which upgraded the Au tenor, as either non-refractory or refractory type, along fracture networks due to the ingress of subsequent base metal-bearing metamorphic fluids (mainly a Pb-Bi association). Furthermore, the data reveal a stratigraphic influence, as reflected in the elemental associations and the elemental enrichments observed and the nature of the sulfide phase hosting the gold mineralization (arsenopyrite versus pyrite).
\end{abstract}

Keywords Banded iron formation · Gold · Elemental association · Geochemistry

\section{Introduction}

Algoma-type banded iron formations (BIFs), which are chemical sedimentary rocks comprised of alternating layers of ironrich minerals (oxides, carbonates, silicates) and chert, represent a significant host rock for gold mineralization in

Editorial handling: D. Huston

Electronic supplementary material The online version of this article (https://doi.org/10.1007/s00126-017-0788-7) contains supplementary material, which is available to authorized users.

B. Gourcerol

gourcerol.blandine@gmail.com

1 Mineral Exploration Research Centre, Harquail School of Earth Sciences, Laurentian University, Sudbury, ON P3E 2C6, Canada

2 BRGM, F-45060 Orléans, France
Precambrian terranes (e.g., Homestake and Musselwhite deposits; Frei et al. 2008; Oswald et al. 2015). The timing and genesis of this style of gold mineralization (syngenetic versus epigenetic models) have been the subject of considerable research and debate over the past few decades and continues in light of new discoveries (Kerswill 1993; Groves et al. 1998; Goldfarb et al. 2001, 2005; Dubé et al. 2015; Steadman and Large 2016).

In the 1970s, some authors suggested a syngenetic model for BIF-hosted gold deposits whereby gold from the ambient water column, although derived from proximal hightemperature vents, was concentrated in arsenian pyrite within the host BIF during chemical sedimentation and/or early diagenesis (Fripp 1976; Kerswill 1993, 1996). However, evidence supporting an epigenetic model included textures suggestive of a replacement origin of the pre-existing BIF (sulfide facies), which were closely associated with the mineralized 
and discordant quartz (-carbonate) vein systems (e.g., Phillips et al. 1984; Phillips and Powell 2010; Poulsen et al. 2000; Dubé and Gosselin 2007). More recent studies of the primary geochemical signature of Algoma-type BIFs using rare earth element (REE) and yttrium (Bolhar et al. 2005; Thurston et al. 2012; Gourcerol et al. 2015a, b, 2016a) have established that gold mineralization hosted by BIF may occur irrespective of their paleo-tectonic setting, that is, not related to proximal vent sites. Thus, the current consensus is that gold mineralization is epigenetic and related to the same metamorphic/hydrothermal processes typically associated with orogenic gold systems (Phillips et al. 1984; Phillips and Powell 2010; Poulsen et al. 2000; Goldfarb et al. 2001, 2005). In this model, therefore, the BIF represents an efficient chemical trap given its high $\mathrm{Fe}$ content and thus potential reactive capacity with the reduced, metal- and $\mathrm{H}_{2} \mathrm{~S}$-rich fluids migrating through favorable structures (such as fold hinges, shear zones; e.g., Poulsen et al. 2000; Dubé and Gosselin 2007; Phillips and Powell 2010). However, even in this preferred model, the primary source of gold and the nature of the mineralizing fluids remain problematic (Goldfarb et al. 2005; Phillips and Powell 2010; Large et al. 2011; Goldfarb and Groves 2015).

In recent years, Large et al. (2007, 2009, 2011), based on detailed LA-ICP-MS elemental mapping of sulfides and supporting in situ analysis, have suggested that the mineralization in sediment-hosted gold deposits (Sukhoi Log in Siberia; Bendigo in Australia; Spanish Mountain in British Columbia, Canada; North Carlin Trend, Nevada, USA) originated from the mobilization of primary $\mathrm{Au}$ enriched from early diagenetic, fine-grained, and/or framboidal pyrite in carbonaceous sediments such as black shales. The latter sulfides were considered to have originally precipitated in anoxic bottom waters of large basins (Scholz and Neumann 2007) due to the mediating influence of sulfatereducing bacteria (Schieber 2002; Folk 2005; Large et al. 2014) with concomitant enrichment of the sulfides in many trace elements including As, Mo, Ni, Pb, Zn, Te, V, and Se. Subsequent deformation and metamorphism (generally greenschist facies) and/or intrusive activity resulted in recrystallization of the host sulfide and its subsequent conversion to coarse-grained pyrite and/or pyrrhotite with the concomitant release of its contained $\mathrm{Au}$ and other metals into the fluid phase. The transport and structural focusing of these metalliferous fluids are thus considered to have formed a variety of quartz-carbonate-sulfide veins and disseminated sediment-hosted gold deposits (Wagner et al. 2007; Large et al. 2011; Cook et al. 2013; Bull and Large 2015). In this context, an important question is whether gold mineralization in BIF-hosted gold deposits originates from similar source rocks (such as black shales) with an early metal enrichment in diagenetic sulfide phases which was subsequently released into an oreforming fluid (Steadman et al. 2014; Gao et al. 2015).

In this study, we examine the textures and trace element zoning of pyrite, pyrrhotite, and arsenopyrite, as determined using laser ablation (LA) mapping methods (see below), from three BIF-hosted gold deposits in the Archean of Canada in order address the following: (1) identify element associations that characterize the gold event(s); (2) evaluate the potential sources of the metals; and (3) establish, where possible, the features of the mineralizing fluid. The deposits studied include (1) the $\sim 4-\mathrm{Moz} \mathrm{Au}$ Meadowbank deposit; (2) the $\geq 2.8-\mathrm{Moz}$ Au Meliadine district; and (3) the $\sim 6-\mathrm{Moz}$ Au Musselwhite deposit (Fig. 1). The procedures employed to address the abovementioned fundamental questions include (1) assessing the distribution of $\mathrm{Au}$ and various trace elements in goldhosting sulfides; (2) use element maps generated from the LA-ICP-MS mapping to determine element paragenesis and thus relative timing in addition to associations; and (3) comparison of the results from the studied areas with those for other orogenic gold deposits, such as clastic sediment-hosted gold deposits, in order to establish similarities or differences in the gold reservoir and associated elements.

\section{Geological setting of the selected BIFs}

\section{The Meadowbank deposit}

Located in the Rae Domain of the Western Churchill Province (Fig. 1, ESM 1), the Meadowbank deposit is hosted by the Woodburn Lake greenstone belt (ca. $2.71 \mathrm{Ga}$ ) which consists of tholeiitic and komatiitic metavolcanic rocks with calc-alkaline, intermediate to felsic tuffs and flows, intercalated BIF, and clastic metasedimentary rocks including quartzite and conglomerates (Armitage et al. 1996; Sherlock et al. 2001a, b, 2004; Hrabi et al. 2003; Pehrsson et al. 2004; Janvier et al. 2015). The metamorphic grade ranges from middle greenschist to lower amphibolite facies (Pehrsson et al. 2004) and rocks were subjected to at least four deformation events related to the Proterozoic Trans-Hudson orogeny (Pehrsson et al. 2013; Janvier et al. 2015). Both the regional and deposit scale geological maps and interpretation are well documented in Pehrsson et al. (2013) and Janvier et al. (2015).

Numerous units of oxide-, silicate-, and locally sulfidefacies BIF occur in the deposit area (ESM 1, 2A, B; Gourcerol et al. 2015a; Sherlock et al. 2001a, b, 2004). Despite chemical, mineralogical, and textural similarities, only the "Central BIF" contains economic Au concentrations (Janvier et al. 2015). Based on previous work, one gold event is recognized, as illustrated by the presence of fracture-fills and/or as micro-inclusions in pyrite. This gold event is constrained as prior to $1.85 \mathrm{Ga}$ (i.e., the Trans-Hudson orogeny) mainly based on structural evidence such as occurrence of transposed-boudinaged high grade gold-quartz veins transposed into the composite S2 foliation (Janvier et al. 2015) and is characterized by an elemental association of anomalous As, $\mathrm{Cu}, \mathrm{Pb}, \mathrm{Ni}, \mathrm{Co}$, and $\mathrm{Te}$ as determined by solution ICP-MS analysis (Armitage et al. 1996; Janvier et al. 2015). 


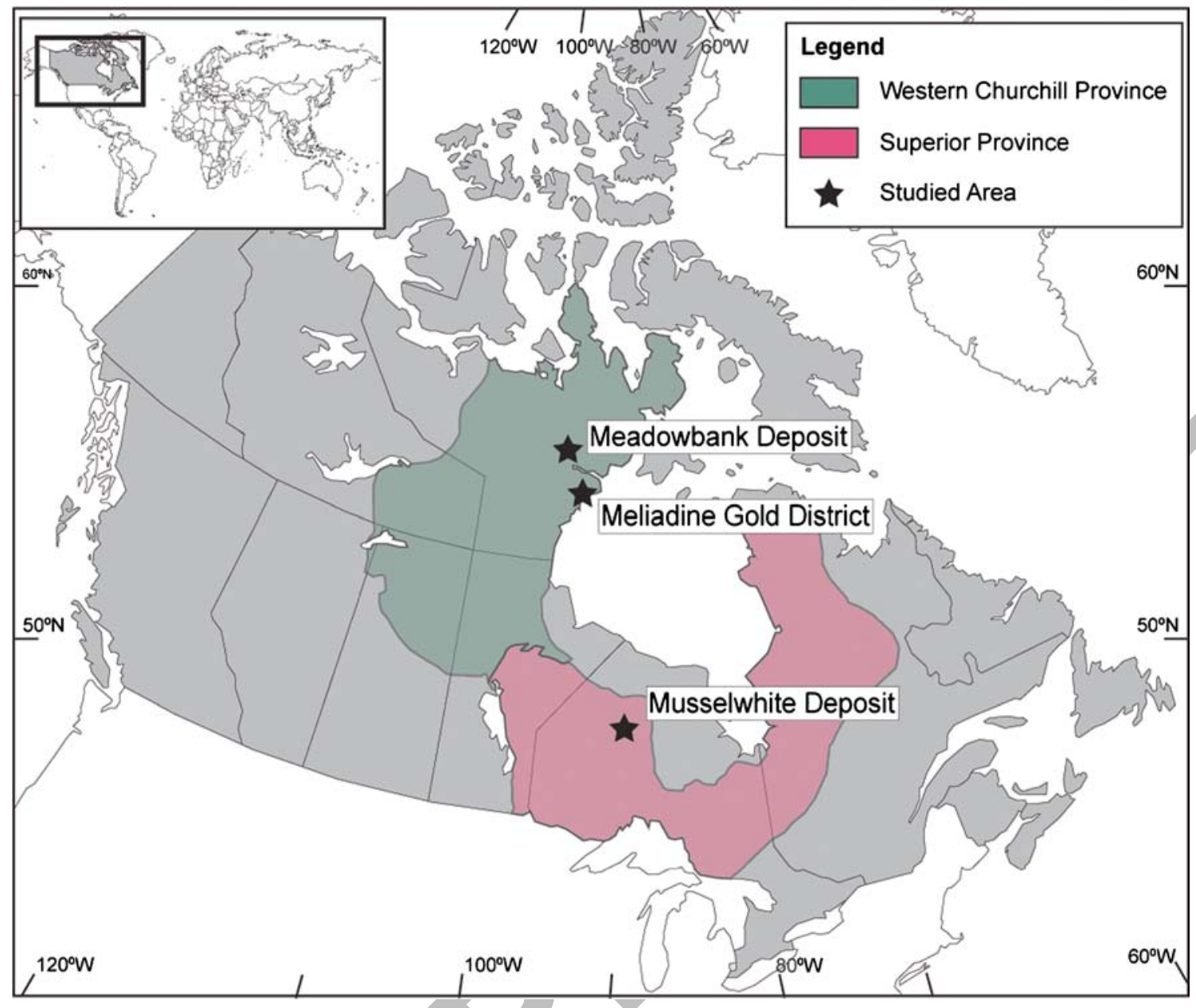

Fig. 1 Simplified map showing the location of the Meadowbank and Meliadine areas in the Western Churchill Province and the Musselwhite deposit in the Superior Province (Canada) (modified from carte-du-monde.net)

\section{Sulfide paragenesis at the Meadowbank deposit}

The Central BIF shows a complex sulfide paragenetic sequence based on examination of 33 polished thin sections of selected samples. The mineralization is characterized by the presence of three pyrite events (py1, py2, py3), formation of metamorphic pyrrhotite, and the presence of minor chalcopyrite and arsenopyrite inclusions and/or disseminated grains in magnetite bands or in metamorphic pyrrhotite. The earliest pyrite (py1 and py 1'; note that py 1' is considered as an early pyrite (py1) incorporated in py2) consists of aggregates (< $100 \mu \mathrm{m}$ ) of sooty, fine-grained material with what we interpreted to be a "framboidal-like" texture (Fig. 2a, b, d). (c) pote that this texture is not well preserved since it has been Cpraced by later pyrite (py2) and that the texture may be interpreted differently due to its subtle nature. However, most relevant to the timing of py1 is that it tarnishes faster than py 2 and is thus easily observed as being enclosed in py2 (Fig. 2a, b), a relationship that would not be obvious on freshly polished sections. Based on this observation, it is suggested that py 1 is the vestige of an early growth stage during diagenesis, which is not uncommon in gold mineralized settings in metasedimentary rocks (e.g., Large et al. 2007). This pyrite is overgrown by coarser-grained $(<200 \mu \mathrm{m})$, subhedral to euhedral pyrite (py2) that is characterized by a sieve-texture, due to the presence of abundant inclusions (Fig. 2d) oriented along the foliation, and also pitting which is a reflection of coupled dissolution-precipitation (CDP; Putnis 2002). The py2 may contain fine-grained internal domains and be zoned, which is interpreted as inclusions of py1 partially incorporated within py2 (Fig. 2a, b), in which case these inclusions are referred to as py $1^{\prime}$, as previously mentioned. Finally, the latest pyrite (py3) is euhedral to subhedral and inclusion-free (Fig. 2b, e) compared to py1 and py2. This last stage of pyrite may either be disseminated (Fig. 2e) or surrounding grains of py2 (Fig. 2b). Coarse-grained ( $>200 \mu \mathrm{m})$ metamorphic pyrrhotite appears to replace pre-existing magnetite bands and thereby has incorporated py1 and py2, but it is overgrown by py3 (Fig. 2e). In addition, loeally fine-grained anhedral to subhedral chalcopyrite and arsenopyrite are present as inclusions or disseminations in the margins of pyrrhotite, which suggests they are coeval in origin with this event (Fig. 2f). 
Fig. 2 Reflected light photomicrographs of sulfide minerals from the Meadowbank deposit. a-d Aggregates of finegrained, sooty pyl (pyrite 1), and coarse-grained, sieve-textured py2 hosted in metamorphic pyrrhotite with minor quartz. The presence of inferred inclusions of py1 in py 2 is outlined with dashed black lines. Also, note that in $\mathbf{b}$ the latest stage pyrite (py3) surrounds two grains of py2. e Euhedral to subhedral grains of py3 overprinting magnetite and metamorphic pyrrhotite. f Finegrained, anhedral to subhedral chalcopyrite at the margin of metamorphic pyrrhotite. Ccp: chalcopyrite; Mag: magnetite; Po: pyrrhotite; Py: pyrite; Qz: quartz
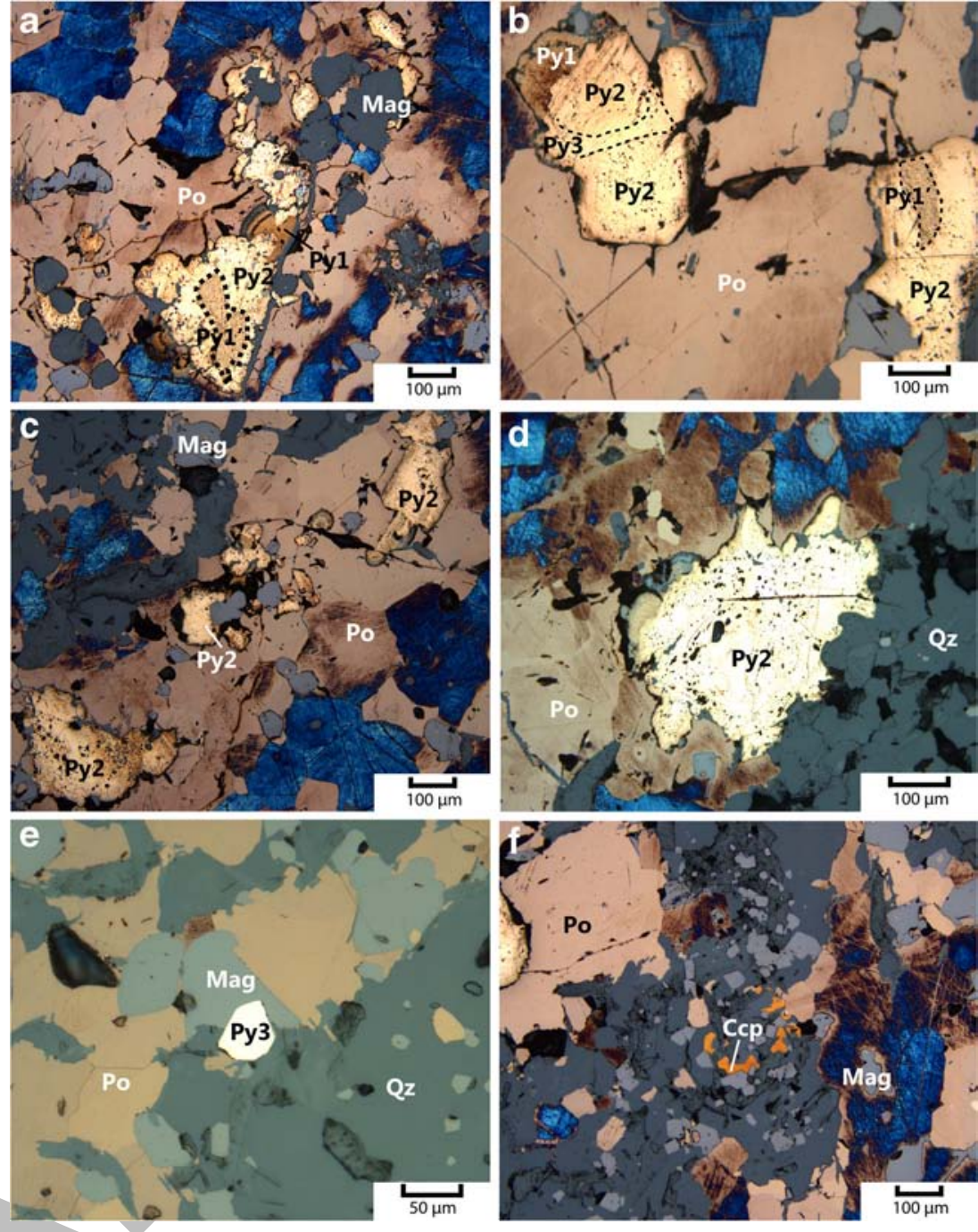

Of particular relevance to the paragenesis and possible diagenetic origin of the earliest pyrite (py1) is its distribution at the Meadowbank deposit area. Based on sample distribution, we note py1 is only present in material from the mineralized BIF within the upper part of the Meadowbank property where the lowest metamorphic grade is pr se t. In contrast, pyl is not present in areas where the metarmorphic grade is higher (i.e., southern part; Gourcerol et al. 2015a). Thus, this observation provides additional support favoring a diagenetic rather than hydrothermal origin for pyl (Scott et al. 2009).

Lastly, Janvier (2016) have independently arrived at the same paragenesis and interpretation of the different pyrite generations. Thus, while the latter does not validate our interpretation of these complex textures, it does provide some corroborating observational support.

\section{The Meliadine gold district}

The Meliadine gold district is hosted by the 2.6-2.7-Ga Rankin Inlet greenstone belt (Wright 1967; Aspler and
Chiarenzelli 1996), which lies along the boundary between the Central and the Northwestern Hearne domains of the Churchill Province (Fig. 1 and ESM 3; Tella et al. 2007; Davis et al. 2008). The Rankin Inlet greenstone belt consists of polydeformed, massive and pillowed mafic flows, felsic pyroclastic rocks and associated interflow sedimentary units, and BIFs. These rock units have been metamorphosed from lower greenschist to lower-middle amphibolite facies (Carpenter 2004; Carpenter et al. 2005). Note that both the regional and deposit scale geological maps are well documented in Carpenter et al. (2005) and Lawley et al. (2015a, b, c, 2017) and thus are not repeated here. Several BIFs which host gold mineralization are recognized, including the oxide-facies Pump and F-Zone BIFs (ESM 2C, D; Gourcerol et al. 2016a). The gold mineralization consists of replacement-style with auriferous quartz-ankerite veins with sulfide alteration selvages. Lawley et al. (2015a, 2017) have shown that gold mineralization is present as either microinclusions and/or as fracture fills cutting the host arsenopyrite (ESM 2E, F, G). Moreover, they also suggest that the Au was 
introduced at either 2.27 and/or $1.90 \mathrm{Ga}$, the latter time representing possible upgrading of the earlier gold during the Trans-Hudson Orogeny based on a new Re-Os arsenopyrite model age presented in their studies. An elemental association of anomalous $\mathrm{As}, \mathrm{Te}, \mathrm{Bi}$, and $\mathrm{Sb}$ associated with the mineralized BIFs was proposed by Lawley et al. (2015a, b, c, 2017) based on whole rock geochemical analyses coupled with LA-ICP-MS element mapping of sulfides.

\section{Sulfide paragenesis at the Meliadine gold district}

A study of 40 polished thin sections which represent sampling from two oxide-facies BIFs on the property (i.e., Pump and FZone) reveals comparable paragenetic sequences. The sulfide phases all occur within quartz-carbonate veins or as randomly oriented grains within vein selvages (Lawley et al. 2015a). In detail, two types of arsenopyrite are distinguished, referred to as apy1 and apy2. Apy1 occurs as strongly fractured, coarse euhedral grains that have a sieve texture (along main fabric) and is considered to represent the primary hydrothermal event (Fig. 3a-e). In contrast, apy2 is fine- to medium-grained, lacks fractures, and is inclusion-free (Fig. 3f). The latter features suggest apy 2 represents a later stage growth. Anhedral to subhedral and locally sieve-textured pyrrhotite, along with pyrite, chalcopyrite, galena, minor sphalerite, and native gold, are present mainly in low-strain, micro-textural sites in apy1 and as fracture-fillings. These phases appear to locally overgrow apy1; hence, they are post-apy1 and pre-apy2 (Fig. 3a-e). A minor sulfide-rich event may have occurred before precipitation of apy1, as rare pyrrhotite and pyrite inclusions are present in apy1 (Carpenter 2004). Elemental mapping of arsenopyrite (Carpenter 2004; Lawley et al. 2015c) confirms the above paragenetic interpretation in the part of the area sampled.

\section{The Musselwhite deposit}

Located in the North Caribou terrane of the Superior Province (Fig. 1, ESM4), the Musselwhite deposit is hosted by the North
Fig. 3 Reflected light photomicrographs of sulfide minerals from the Meliadine gold district. a-e Strongly fractured, coarse-grained, euhedral, sievetextured arsenopyrite crystals associated with anhedral to subhedral grains and aggregates of pyrrhotite, chalcopyrite, and galena along late fractures and/or as inclusions with gold. $\mathbf{f}$ Inclusion-free, fined-grained euhedral apy 2 located along a foliation in a quartz matrix. Apy: arsenopyrite; Au: or; Ccp: chalcopyrite; Gn: galena; Po: pyrrhotite; Qz: quartz
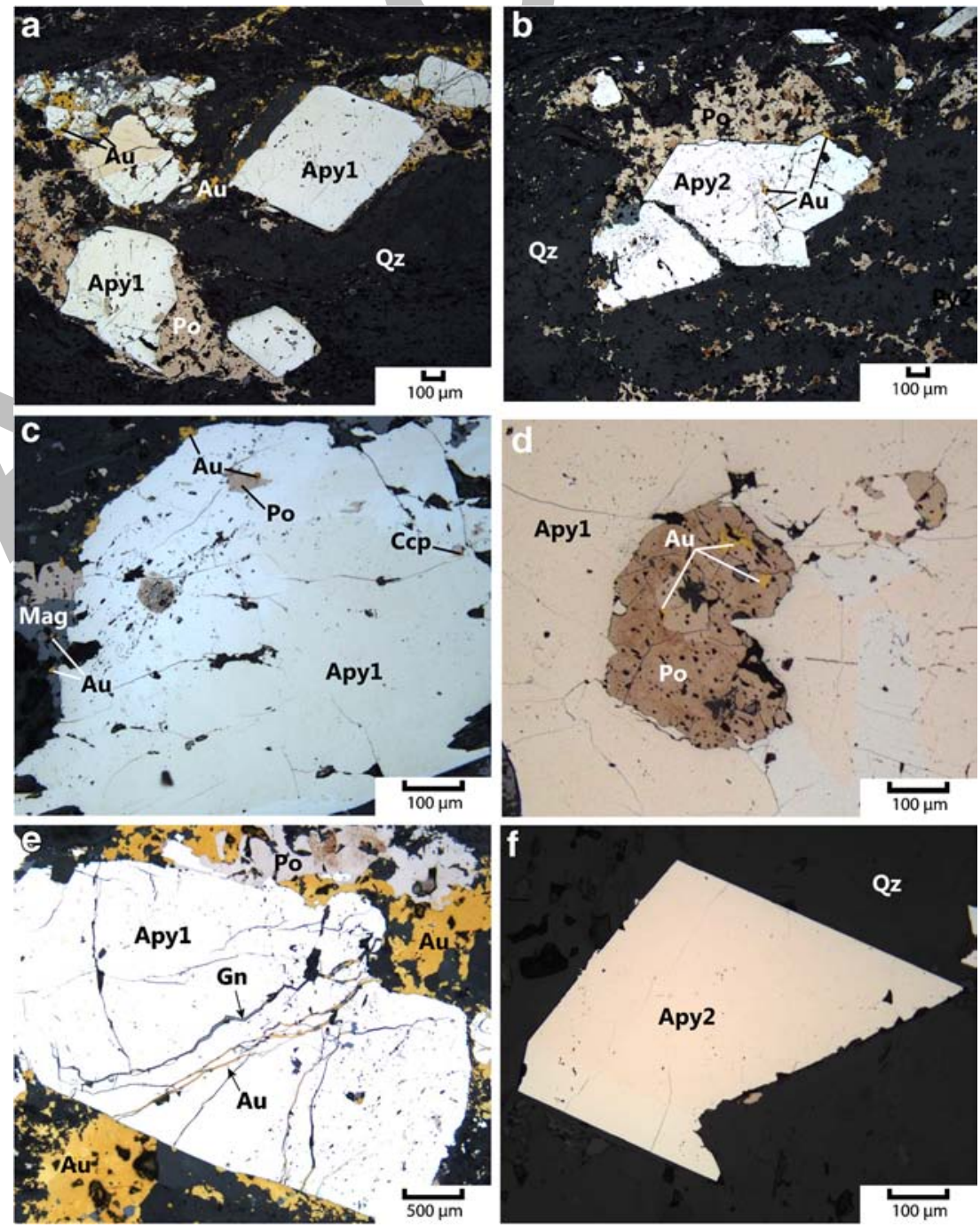
Caribou greenstone belt, which is dominated by mafic to ultramafic metavolcanic rocks of the 2973-<2967-Ma Opapimiskan-Markop assemblage and tholeiitic basalts and minor felsic volcanic rocks of the 2980-2982 Ma South Rim assemblage (Biczok et al. 2012; McNicoll et al. 2016). These rocks were metamorphosed at lower greenschist to low-mid amphibolite facies (Breaks et al. 2001) and deformed by three events (Hall and Rigg 1986; Breaks et al. 2001). Note that regional and deposit scale geological maps along with relevant discussions are documented in Biczok et al. (2012) and Oswald et al. (2015) and thus are not repeated here. Gold mineralization is mainly confined to silicate facies BIFs (ESM 2H, I, J) within high-strain zones along and immediately adjacent to the lower pressure areas such as steep limbs of the folded iron formation (Biczok et al. 2012). Gold occurs mainly within pyrrhotite-filled fractures in coarse-grained, subhedral to euhedral almandine garnet porphyroblasts, and/or in pressureshadows developed along garnet crystals which formed during the $\mathrm{D}_{2}$ event, which is the dominant deformation in the deposit. Thus, the timing of mineralization is inferred to be contemporaneous with garnet crystallization. The timing of the metamorphism related to the gold event is constrained from SHRIMP U$\mathrm{Pb}$ dating of detrital zircon, which yielded ages of 2788 to 2703 Ma (Oswald et al. 2015; Biczok et al. 2012; Kelly and Schneider 2015).

Oswald et al. (2015) proposed an elemental association of anomalous $\mathrm{Ag}, \mathrm{Cu}, \mathrm{Se}$, and $\mathrm{Te}$ with $\mathrm{Au}$ in the BIFs based on whole rock ICP-MS analysis. In addition, elemental mapping of pyrite nodules (Gao et al. 2015) from a carbonaceous argillite unit in the deposit vicinity revealed an elemental association of $\mathrm{Au}, \mathrm{As}, \mathrm{Mo}, \mathrm{Ag}, \mathrm{Sb}, \mathrm{Te}, \mathrm{W}, \mathrm{Tl}, \mathrm{Pb}$, and Bi.

\section{Sulfide paragenesis at the Musselwhite deposit}

The sulfide paragenetic sequence in the mine vicinity, based on examination of 23 polished thin sections, is characterized by several generations of pyrite and formation of metamorphic pyrrhotite in addition to inclusions of minor chalcopyrite and arsenopyrite (Fig. 4). Two types of pyrite are recognized: (1) py1 is present as very fine-grained $(<25 \mu \mathrm{m})$, anhedral to subhedral annealed grains in metamorphic pyrrhotite (Fig. 4a, b), and (2) py2 is present as coarser-grained (> $100 \mu \mathrm{m}$ ), euhedral grains overprinting pyrrhotite (Fig. 4c, d). Coarse- $(>100 \mu \mathrm{m})$ to fine-grained $(<100 \mu \mathrm{m})$ aggregates of metamorphic pyrrhotite appear to replace pre-existing Ferich material, such as magnetite or possibly also py1, and may also form veinlets and/or filling fractures in coarse-grained, almandine garnet porphyroblasts (Fig. 4c). The relationship between annealed pyrite and pyrrhotite suggests that pyrrhotite formed in response to increasing metamorphic grade along with pyrite rather than metamorphic conversion of pyrite to pyrrhotite (Tomkins 2010). This hypothesis is also consistent with the findings of Oswald et al. (2015). Chalcopyrite grains are locally present as inclusions in pyrrhotite, whereas rare arsenopyrite is present as inclusions in pyrrhotite or as coarse euhedral grains (> $100 \mu \mathrm{m}$ ) overprinting metamorphic pyrrhotite or disseminated in the margins of garnets (Fig. 4b, d).
Fig. 4 Reflected light photomicrographs of sulfide minerals from the Musselwhite deposit. a, b Anhedral to subhedral, annealed grains of pyrite and chalcopyrite that are present as inclusions and/or along late fractures in metamorphic pyrrhotite. c Anhedral pyrrhotite inclusions along fractures in porphyroblasts of coarse-grained, almandine garnet. d Subhedral grains of metamorphic pyrrhotite with minor inclusions of pyrite that are overprinted by later stage, subhedral, coarse-grained arsenopyrite with pyrrhotite inclusions. Ccp: chalcopyrite; Grt: garnet; Mag: magnetite; Po: pyrrhotite; Py: pyrite; Qz: quartz

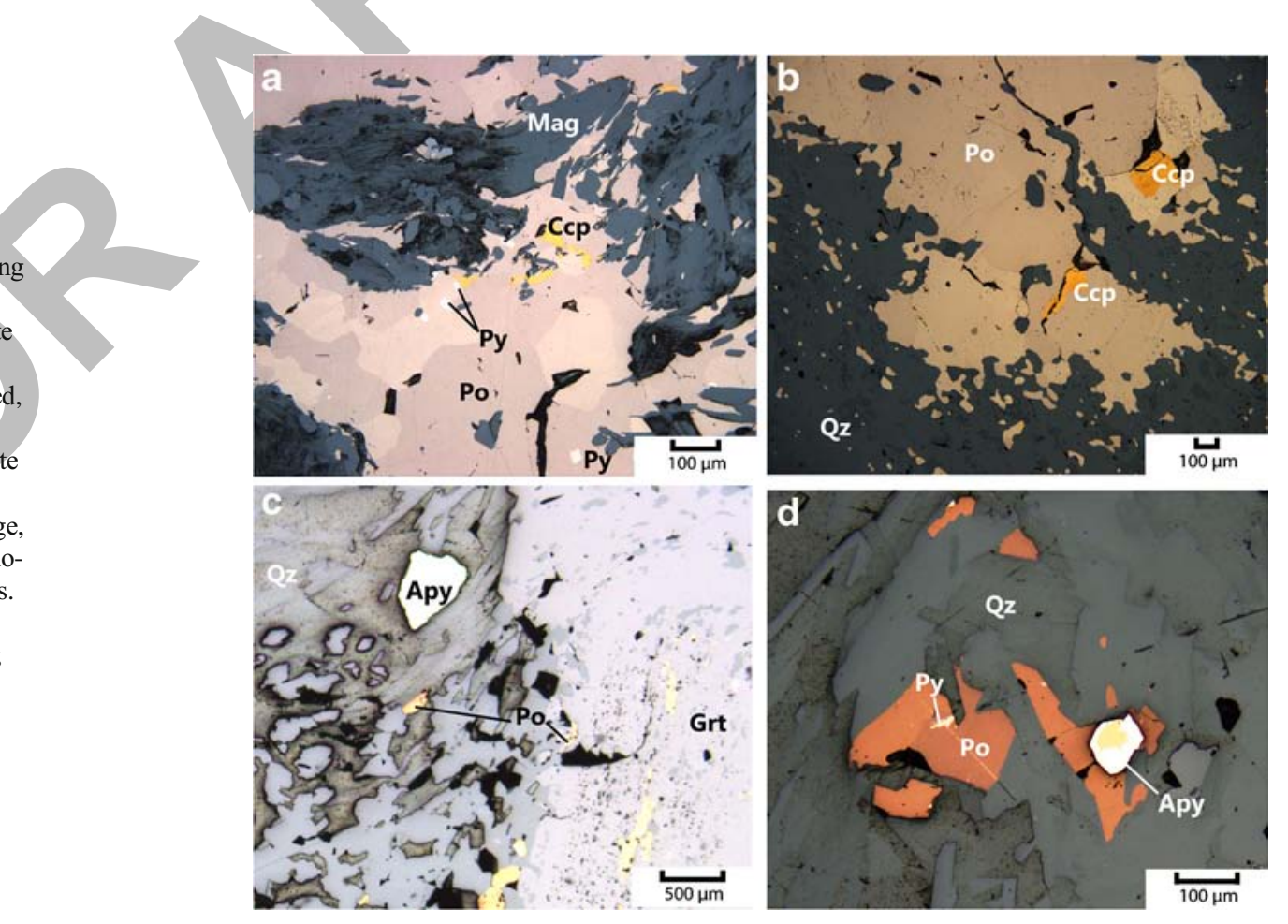


Oswald et al. (2015) suggested the arsenopyrite inclusions do not correlate with $\mathrm{Au}$ tenor.

\section{Analytical methods and data treatment}

\section{LA-ICP-MS sulfide trace element chemistry}

The trace element content of sulfides was determined in the Geochemical Fingerprinting Lab at Laurentian University using a 193-nm wavelength Resonetics RESOlution M-50 ArF excimer laser ablation (LA) system coupled to a Thermo X Series II quadrupole ICP-MS. A series of traverse and map analyses modes were conducted on grains of pyrite, pyrrhotite, and arsenopyrite in thick sections previously characterized by reflected light microscopy and SEM-EDS methods at Laurentian University, Sudbury, Canada. Beam diameters for the LA analyses were typically chosen based on grain sizes of the selected minerals and varied from 9 to $40 \mu \mathrm{m}$. Traverse and map scan rates were approximately $1 / 3$ the beam diameter per second. The laser pulse rate was 7 and $6 \mathrm{~Hz}$ for traverses. In all cases, a fluence of $\sim 5 \mathrm{~J} / \mathrm{cm}^{2}$ was used. Ablation took place in ultra-pure He flowing at a rate of $650 \mathrm{ml} / \mathrm{min}$, which was combined after the sample cell with $\operatorname{Ar}(750 \mathrm{ml} / \mathrm{min})$ and $\mathrm{N}_{2}(6 \mathrm{ml} / \mathrm{min}$; for added sensitivity). The RESOlution M-50 employs a Laurin Technic two-volume sample cell with excellent washout characteristics (Müller et al. 2009) and therefore provides good spatial resolution for traverses and maps. For all analyses, $30 \mathrm{~s}$ of washout/ background was collected before each analysis and reference materials were typically analyzed bracketing and between every several unknowns. The elemental maps were acquired by rastering the laser over the region of interest with successive lines offset by the beam diameter. The ICP-MS was operated with a forward power of $1450 \mathrm{~W}$ and oxide production rate of $<0.5 \%$ as determined from $\mathrm{ThO}+/ \mathrm{Th}+$ while ablating NIST 612. Dwell times were $10 \mathrm{~ms}$ for each analyte except $\mathrm{Au}$, which was $30 \mathrm{~ms}$. All data acquisition was done in timeresolved mode in order to understand the spatial relationships between elements and mineral growth.

Data quantification was carried out using the trace element data reduction scheme of the Iolite software (Paton et al. 2011) with NIST 610 and Fe acting as the external and internal references, respectively. Secondary reference materials BHVO2-G and Po725 (Sylvester et al. 2005) were also analyzed to verify the reasonable reproduction of known compositions. Considering the differences in ablation between silicate glass (NIST 610) and sulfides, it is expected that melting and fractionation limits the accuracy of the quantified data to $\sim 20 \%$ (Wohlgemuth-Ueberwasser and Jochum 2015). The limits of detection for integrated data were calculated according to Longerich et al. (1996) and Howell et al. (2013) (for analytes with no background counts) and were typically 0.01 to $1 \mathrm{ppm}$ for trace elements depending primarily on beam diameter and the analyte background signal.

A new approach to treating the raster (i.e., mapping) and traverse data uses a time-slice technique, similar to that employed by Neyedley et al. (2017); the latter data were also produced and treated from the same laboratory at Laurentian University. The time-slice (not averaged) data, which equate to a single analysis collected each $0.35 \mathrm{~s}$ based on the analytical procedures used in this study (see above), is hence a proxy for a spot analysis (see details in Gourcerol et al. 2016b). These data are then used in the binary plots and profiles presented below which provides the means to assess the relationship among large data sets, which in this case may involve upwards of 35,000 data points of which each has numerous elements detected. The data are subject to higher detection limits than point analyses but were not quantified as it is the elemental associations that are of interest in these plots. Maps were originally stitched together using Iolite (e.g., Woodhead et al. 2007) but were also subjected to bilinear interpolation between adjacent lines and $3 \times 3$ mean pixel smoothing. This improves the visualization of the data but can also reduce or eliminate spikes resulting from the ablation of tiny inclusions (e.g., Rittner and Müller 2012). The traverse data used for all bivariate plots included herein were not smoothed in any way.

\section{Determination of pyrite origin}

Large et al. (2009) studied four sediment-hosted gold deposits (i.e., Sukhoi Log, Bendigo, Spanish Mountain, North Carlin Trend) and reported LA-ICP-MS data from early diagenetic pyrite and their corresponding recrystallized metamorphic/ hydrothermal pyrite within orogenic and Carlin-type settings. This work followed on more detailed studies of, for example, Sukhoi Log (Large et al. 2007), where it was shown that paragenetically early, framboid-textured pyrite is metal-rich (including $\mathrm{Au}$ ) and the later recrystallized equant pyrite is metal depleted; this observation provided the basis for their model presented in this and subsequent papers whereby transformation of this early pyrite to the later pyrite liberates $\mathrm{Au}$ which forms concentrations in orogenic style deposits (Large et al. 2009). Using the analytical data presented in the latter paper, we have defined empirically based discrimination fields, which are presented here for the first time, based on the observation that data for different textural varieties of pyrite (early framboidal versus later metamorphic) from these deposit settings are distributed differently in a binary Ag versus Ni plot (Fig. 5). Although this diagram is empirically based, it is nevertheless used to make several inferences about the analyzed pyrite in the present study: (1) distinguish the origin of various pyrites (primary versus recrystallized pyrite); (2) determine potential element sources and associations within these sulfides; and (3) assess the geochemical nature of the gold event(s). The intent herein is to use this diagram and test 
Fig. 5 Binary plot of Ag versus $\mathrm{Ni}$ (ppm) for pyrite from four different sediment-hosted gold deposits using data presented in Large et al. (2009) on Sukhoi Log, Bendigo, Spanish Mountain, and the North Carlin Trend. The distribution of the trace elements in these pyrites provides the basis for distinguishing early diagenetic (red field), versus metamorphic/ hydrothermal orogenic (blue field) and Carlin-type (green filed) pyrite via decoupling/ precipitation processes

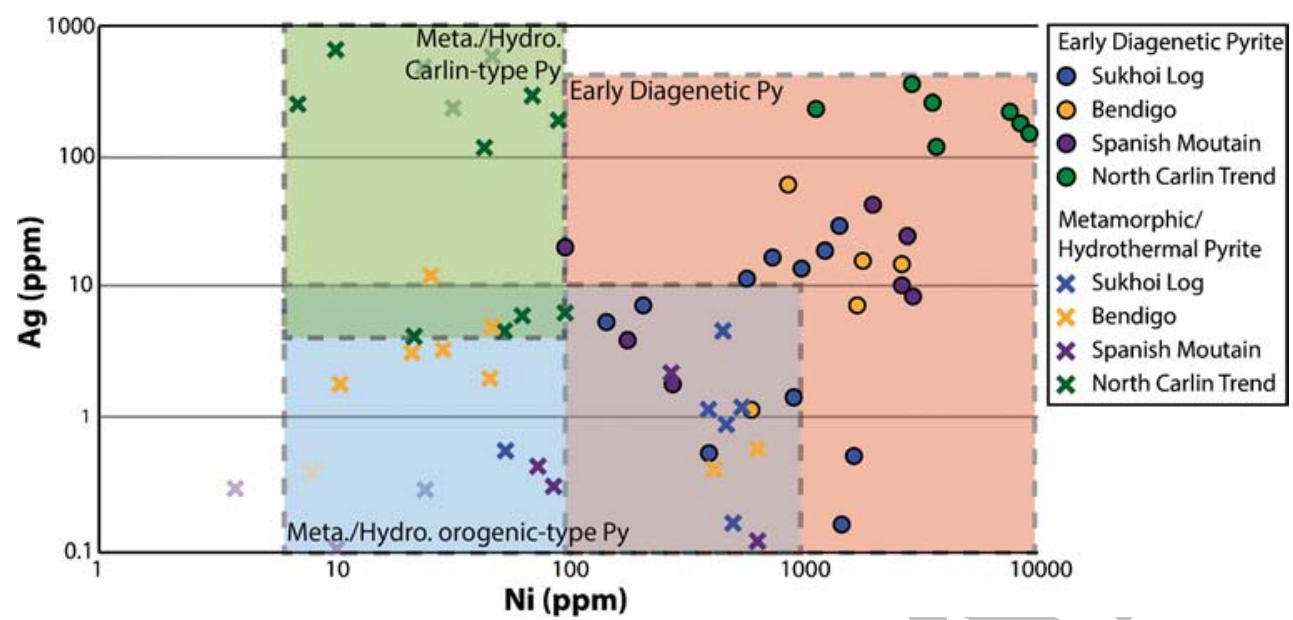

it in the context of current data set and going forward see how other workers may apply it is similar studies in much that same way as discriminant diagrams have been used for example in igneous petrology (Rollinson 1993).

\section{Results and interpretation}

Due to the highly variable level of previous knowledge and types of analyses available for samples from these deposits (Janvier et al. 2015; Janvier 2016; Lawley et al. 2015c; Oswald et al. 2015), LA-ICP-MS mapping was done on pyrite for the Meadowbank deposit, whereas only LA-ICP-MS traverse mode analyses were done for arsenopyrite from the Meliadine gold district and on pyrrhotite and arsenopyrite from the Musselwhite deposit.

\section{The Meadowbank deposit}

\section{LA-ICP-MS trace element chemistry}

LA-ICP-MS element distribution mapping was performed on an aggregate 2 ainly py 1 and py 2 with lesser py 3 within sulfidized oxide-fact IF in the Central BIF (Fig. 6). The texture of py1, as previously discussed above, is interpreted to reflect an early, possibly diagenetic origin and is overgrown by coarser-grained, sievetextured py2 (Fig. 6a). Finally, py 3 which is free of a sieve texture and thus a different pyrite generation may equate to the latest type of pyrite (py3) in the Meadowbank deposit. The elemental maps display a zonation which reflects variation in metal availability during the growth of these different pyrites (py1, py2, py3). The following features are noted in regards to these maps: (1) the core of py1 is relatively enriched in Mo compared to py2, with lesser $\mathrm{Co}, \mathrm{Ni}$, and $\mathrm{W}$ and only very minor to trace amounts of $\mathrm{Sb}, \mathrm{Pb}, \mathrm{Ag}$, $\mathrm{Bi}$, and $\mathrm{Au}$; (2) py2 has two distinct domains enriched in either $\mathrm{W}$ or $\mathrm{Tl}$, but the cores of both show elevated $\mathrm{Co}$ and Ni. These domains are notably depleted in $\mathrm{Bi}, \mathrm{Au}, \mathrm{Mo}$, and $\mathrm{Cu}$. We note that the py 2 chemical signature departs markedly from that of py 1 ; (3) py3 (at the interface of py 2 domains) shows the most enrichment in Co, $\mathrm{Ni}, \mathrm{Pb}, \mathrm{Ag}, \mathrm{Bi}$, and lesser $\mathrm{Sb}$. That this domain is completely different chemieally to that of py 2 implies that it is not part of py 2 and instead forms a distinct phase separating the two domains of py 2 , hence it is a later stage pyrite which is assigned py3; and lastly, (4) there is a notable enrichment of $\mathrm{Mo}, \mathrm{Au}, \mathrm{Sb}$, and lesser $\mathrm{Cu}$ on the margins of py 2 which may therefore represent another distinct metal enrichment event.

In order to better understand elemental distribution, we use the individual time-slice data from the maps and the results are shown in selected binary plots in Fig. 7. It is apparent in the latter plots that the data fall into two fields, albeit with a continuum, which essentially reflects either relative enrichment or depletion of Ni. Based on where the data fall in the proposed fields of these diagrams (Fig. 7), it appears that the three distinct textural types of pyrite may on this basis correspond to early diagenetic and later metamorphic/hydrothermal types. The latter is seen therefore to support the interpretation of the above petrographic observations.

Further examination of the elemental distribution in these pyrites suggests possible relative element enrichment/depletion which relates to specific processes. Thus, it appears that py1 corresponds chemically to an early stage of pyrite growth defined by the elemental associations, albeit at low levels for some of these, of $\mathrm{Co}, \mathrm{Ni}, \mathrm{Pb}, \mathrm{Ag}, \mathrm{Bi}, \mathrm{Mo}, \mathrm{W}$, and $\mathrm{Sb}$. Whether this is in fact a remnant diagenetic feature can be debated, but the maps clearly indicate this domain is chemically distinct from py 2 and py3. These elements were subsequently remobilized during the conversion of the early py 1 to py2, a later metamorphic/ hydrothermal orogenic-type, via a coupled dissolutionprecipitation processes (Putnis 2002) based on petrographic observations. The latest stage; py3; appears to crosscut py 2 in the elemental maps and thus must be a later stage event.

Figure 7 demonstrates that the dataset gathered from these three pyrite types illustrates an early diagenetic (py1) and metamorphic processes (py2 and py3). The various binary plots 

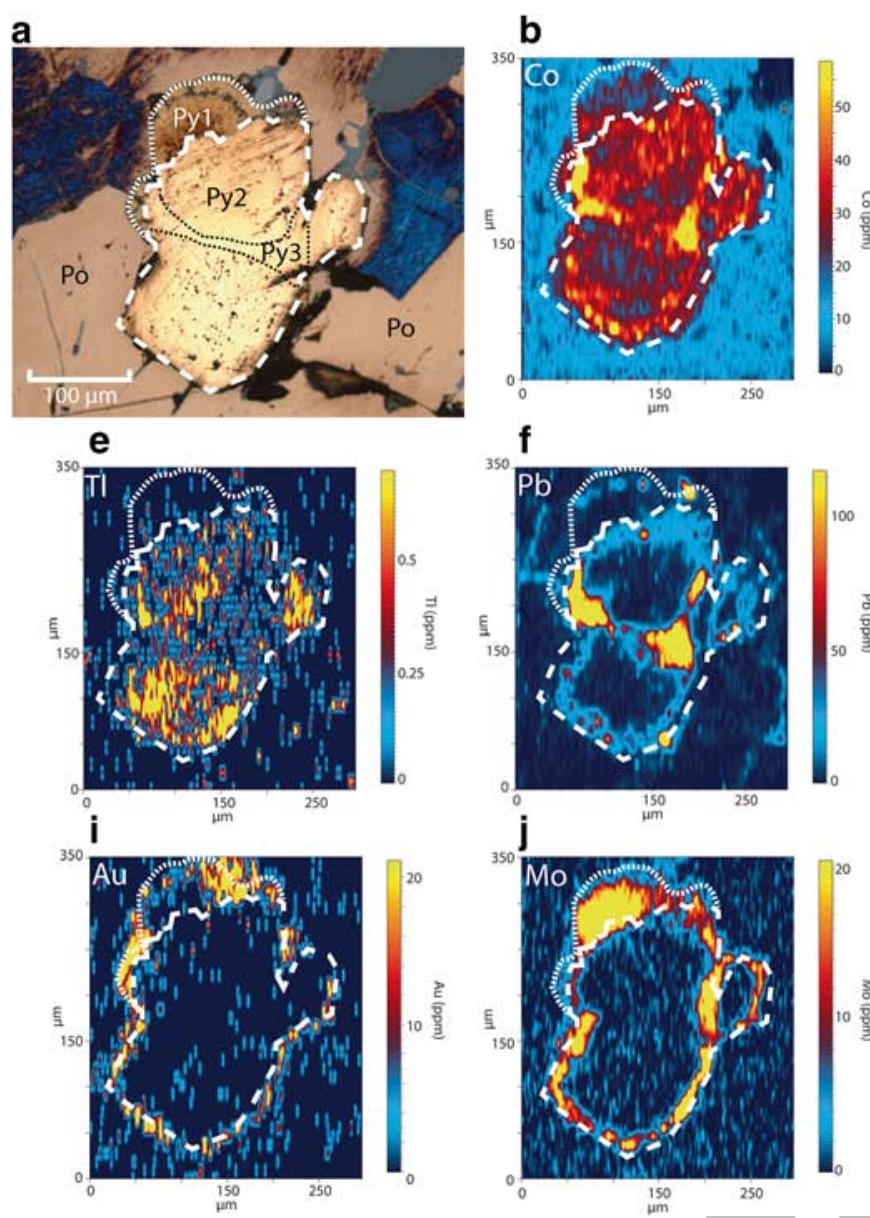

Fig. 6 Elemental maps generated with LA-ICP-MS which show the distribution of selected trace elements in different pyrites (py1, py2, py3 aggregate) from sulfidized part of oxide-facies BIF (Meadowbank deposit). a Reflected light photomicrograph of the mapped pyrite crystals (py1, py2, and py3) that occur in a matrix of metamorphic pyrrhotite, b-I Different element maps plotted as concentrations scaled between the data

(Fig. 7) clearly highlight elemental enrichments and, in the case of $\mathrm{Bi}$ and $\mathrm{Sb}$, allow a clear subdivision into two groups that probably relate to py 1 and py 3 (Fig. $7 \mathrm{~d}, \mathrm{j}$ ). Thus, the gold enrichment, which surrounds py2, is considered to reflect introduction by late metamorphic/hydrothermal processes based on the distribution of the Au data in Fig. 7a, as the most enriched part of the binary plot overlaps with the beginning of the metamorphic pyrite field. The latter is also seen to be characterized by an elevated 20 iation of $\mathrm{Bi}, \mathrm{As}, \mathrm{Se}, \mathrm{Sb}$, and $\mathrm{Te}$ (As and Te element maps are nor mcluded in Fig. 6 due to their relatively low concentrations). Of note is the spread of the latter data in the binary plots, which contrasts with the more concentrated values for both $\mathrm{W}$ (Fig. 7e) and Mo (Fig. 7f) with the highest values centered near the higher $\mathrm{Co}$ and Ni values. Specifically, regarding Au in the mapped area, the following is also noted: (1) Au does not appear to have originated from the early py1 and (2) the locally high content of Au in py1 (i.e., likely nanoparticles) may reflect late precipitation of gold in porous areas of pyl. Moreover, considering the
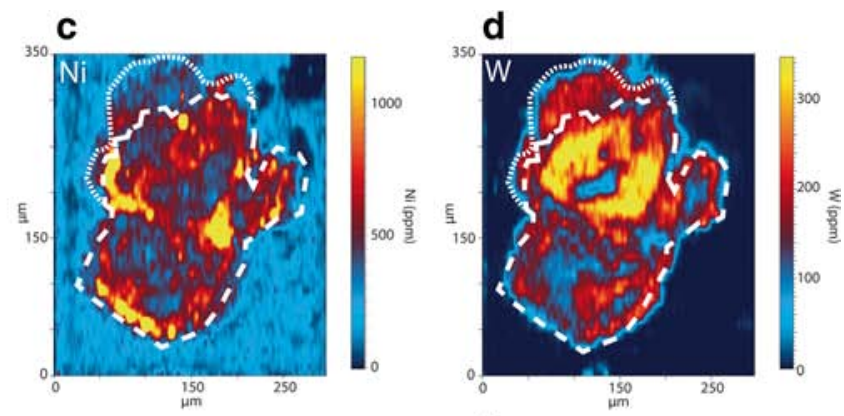

g

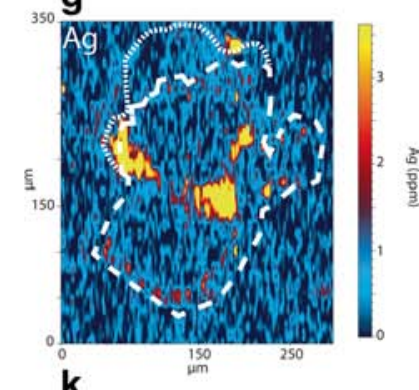

h
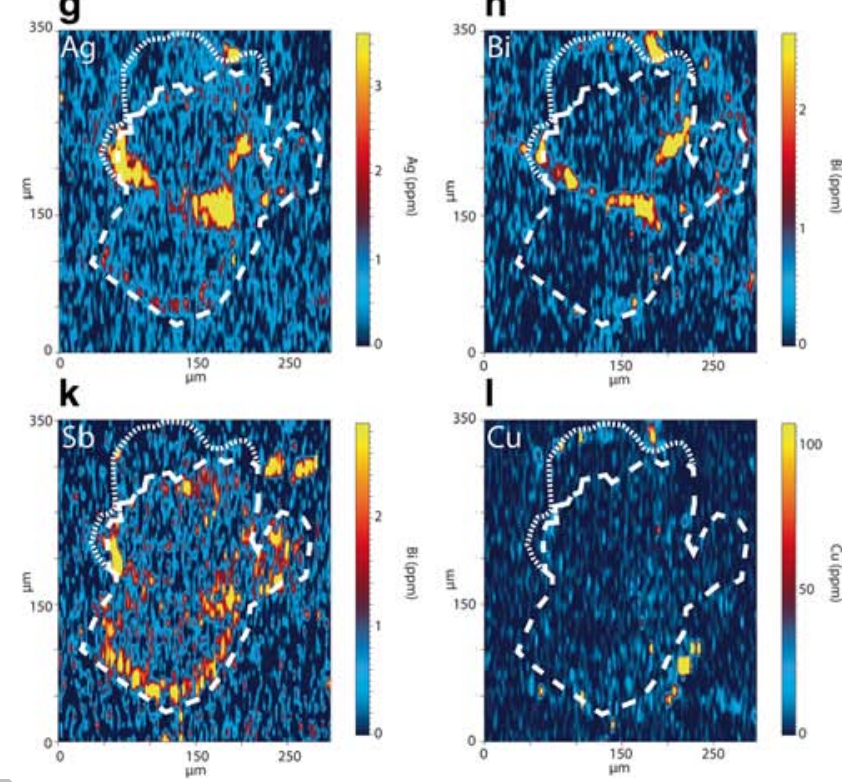

median $+/-3$ standard deviations. This plotting was used to maximize the contrast for most of data while maintaining a linear scale and, therefore, the maximum concentrations of the scale are not the true maximums present in the sample. Note that white dashed lines on element maps outline the distribution of py 1 and py 2 and black dashed line the py 3

distribution of selected elements throughout the early py1 (Co, $\mathrm{Pb}, \mathrm{Ni}, \mathrm{W}, \mathrm{Mo}$ ) and the similar behavior of As-Se-Te to $\mathrm{Au}$ (Figs. 6 and 7), only one gold event is suggested in this sample based on Fig. 71. It is also noted that highest $W$ values are in py2 compared to py1, which agrees with the metamorphic fluid circulation model suggested by Pitcairn et al. (2010) and Large et al. (2012) whereby this W enrichment relates to metamorphic recrystallization of W-bearing phases, such as detrital rutile to metamorphic titanite, which liberates W (Cave et al. 2015).

An aggregate of three subhedral to euhedral py2 grains along a chert band in silicate facies BIF was also mapped to further characterize the nature of py2 (Fig. 8). Distinct metal enrichments were identified: (1) two of the grains display isolated Ni-As-Se enrichment in their cores, hence during the early growth stage of these grains, which are surrounded by distinctive $\mathrm{Co}(-\mathrm{As})$-rich and $\mathrm{Ni}$-Se-rich outer growth zones; (2) one of the pyrite grains displays a Co-As(-Se) and $\mathrm{Ni}$-As-Se enrichment during initial formation suggesting the 
a

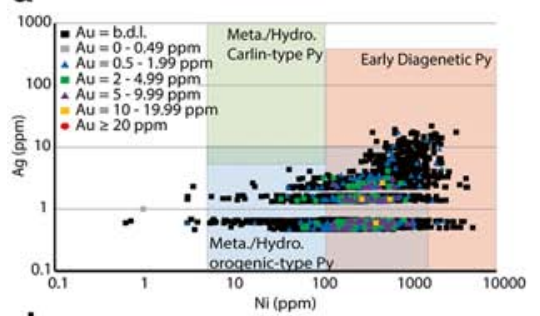

d

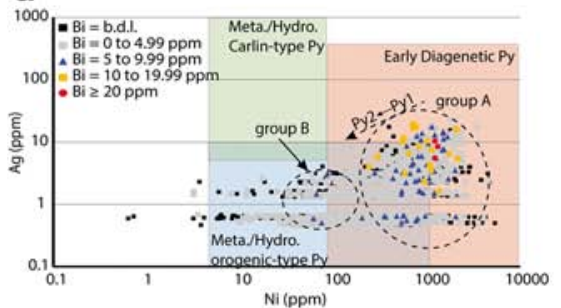

g

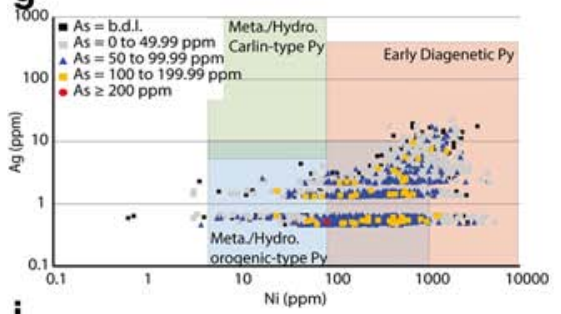

j

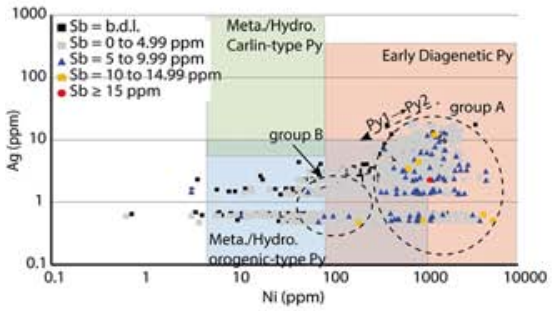

b

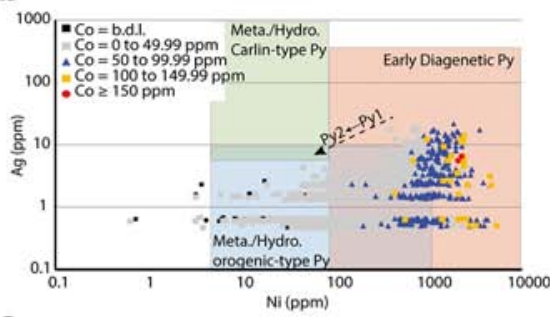

e

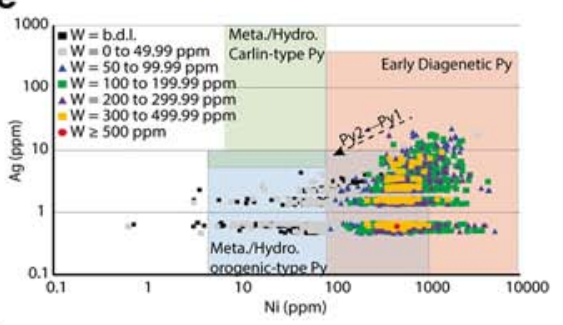

h

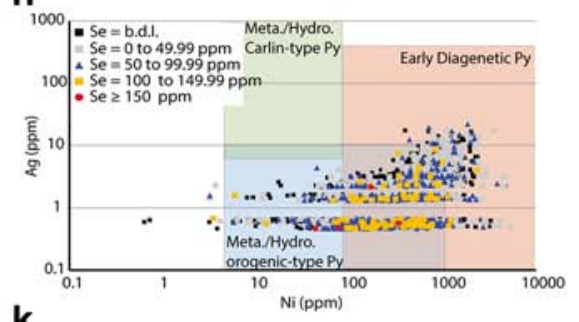

k

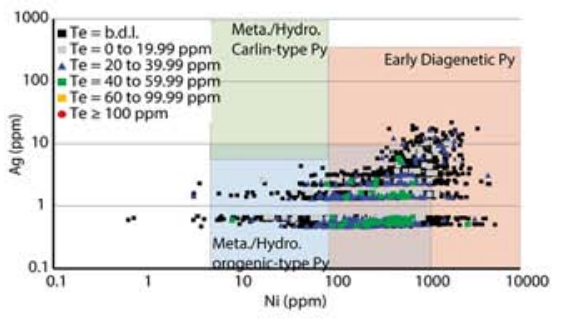

C

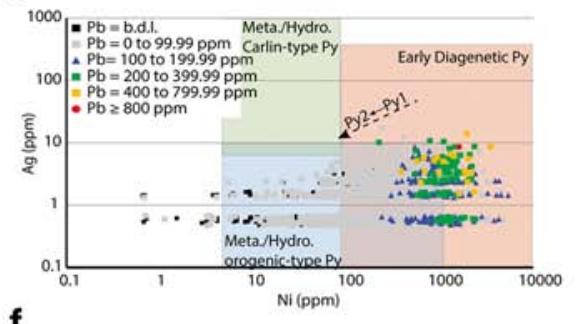

f

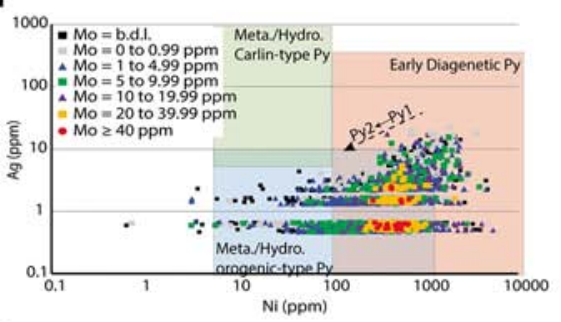

i

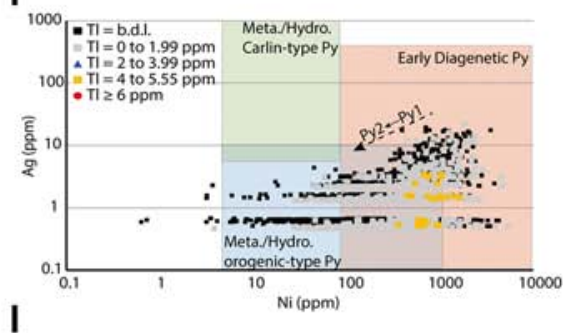

I

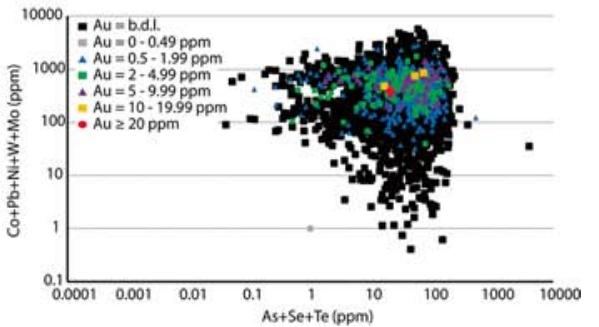

Fig. 7 Selected binary element plots (ppm) illustrating the distribution of trace elements among different pyrites (py1, py2, py3 aggregate) from the sulfidized part of oxide-facies BIF (Fig. 7). a-k Binary element plots of Ag versus Ni grouped by selected trace elements which show the distribution in the pyrite fields defined (cf. Fig. 6) using data in Large et al.
(2009). I Plot of $\Sigma(\mathrm{Co}+\mathrm{Pb}+\mathrm{Ni}+\mathrm{W}+\mathrm{Mo})$ versus $\Sigma(\mathrm{As}+\mathrm{Se}+\mathrm{Te})$ grouped by $\mathrm{Au}$ content. Note that the detection limit for $\mathrm{Ag}$ is at about $0.4 \mathrm{ppm}$. Groups A and B refer to element remobilization during the conversion of py1 to py2 via dissolution-precipitation processes which resulted in formation of the metamorphic/hydrothermal orogenic-type py2 presence of two distinct grains, as well as a distinct Co-Ni-AsSe outer growth zone. Finally, all the pyrite grains are overgrown by a thin layer enriched in $\mathrm{Mo}, \mathrm{Sb}, \mathrm{Te}, \mathrm{Bi}$, and $\mathrm{Ag}$. Despite values close to the detection limit, the elemental maps suggest the presence of Au as inclusions (Fig. 81).

The results of the time-slice domain data are presented in binary element plots in Fig. 9 overlain by the different inferred fields as noted in the previous diagram for pyrite (Fig. 7). For the present pyrite sample, we note that there is a similar distribution of data in the Ag versus Ni plots (Figs. 7 and 9) despite the notable absence of textural evidence for these pyrites having features suggestive of an early diagenetic stage of growth (py1). This latter feature provides evidence for an orogenic metamorphic/hydrothermal affinity of py2, formed in part from the coupled dissolution/precipitation of earlier diagenetic pyrite either in oxide or silicate facies BIF. The distribution of the trace elements (Fig. 8) indicates variable element associations, as follows: (1) $\mathrm{Co}, \mathrm{As}, \mathrm{Ni}$, and variable $\mathrm{Se}$ reflect formation of core zones, as seen in the pyrite maps; (2) Ag, Mo, $\mathrm{Sb}, \mathrm{Te}, \mathrm{Bi}, \mathrm{Pb}$, and variable $\mathrm{Se}$ reflect a later stage overgrowth on the py2 aggregate; and (3) the presence of minor inclusions of a $U$ phase randomly distributed through the host pyrites. The distribution of Au reflects two distinct trace element associations: (1) $\mathrm{Co}$ ( \pm $\mathrm{Se}, \mathrm{Bi}, \mathrm{Pb}, \mathrm{Te}$ ) along with low $\mathrm{Ag}$ contents, which was not clearly seen in the elemental maps of Fig. 8 due to the low Au content, and (2) high $\mathrm{Ag}( \pm \mathrm{Sb}, \mathrm{Te}, \mathrm{Se}, \mathrm{Bi}, \mathrm{Pb})$ which may reflect inclusions in py 2 based on the maps (cf. white arrows on Fig. 9). Considering the plot of $\mathrm{Mo}-\mathrm{Sb}-\mathrm{Te}-\mathrm{Bi}-\mathrm{Pb}$ versus $\mathrm{Co}-\mathrm{As}$ (Fig. 9k), which correlates with, respectively, the metal-rich rim and core areas of pyrite, two 


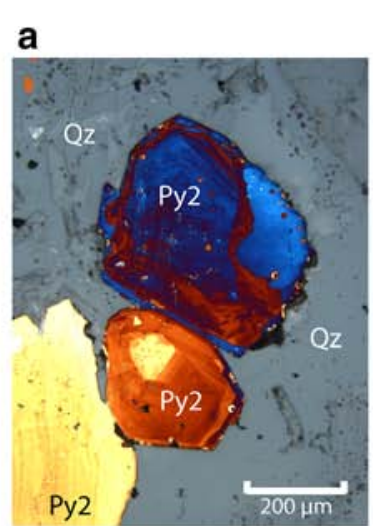

e

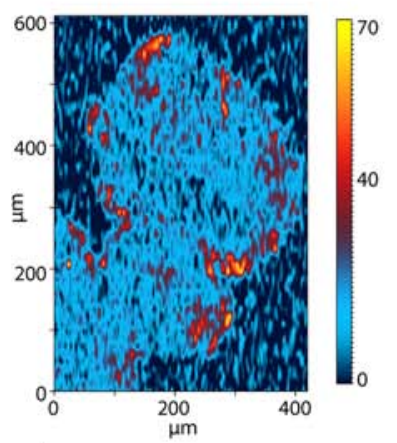

i

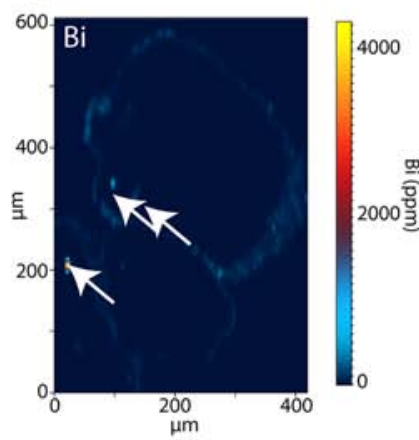

b

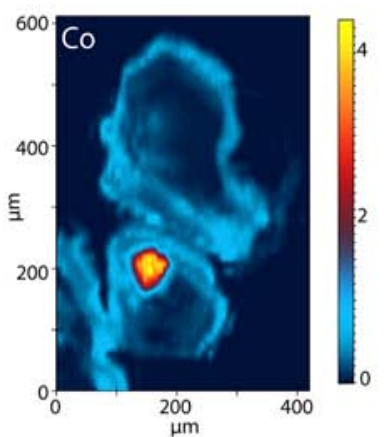

f

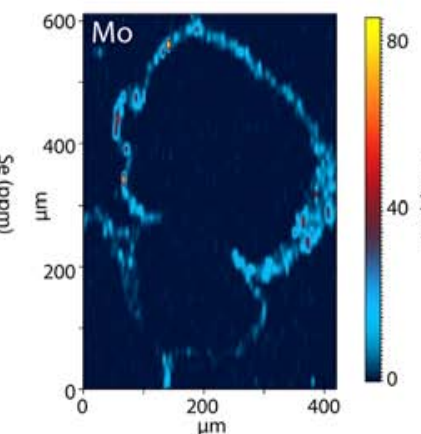

j

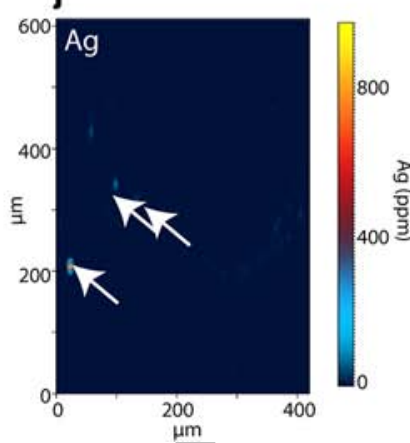

$\mu \mathrm{m}$
C

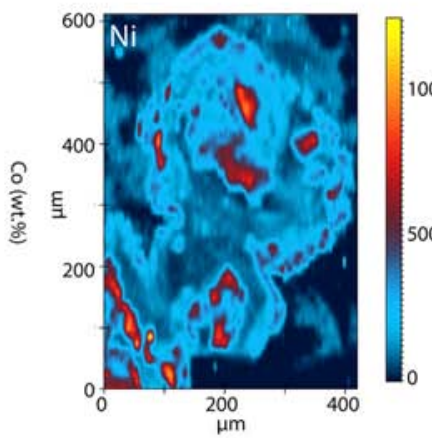

\section{g}

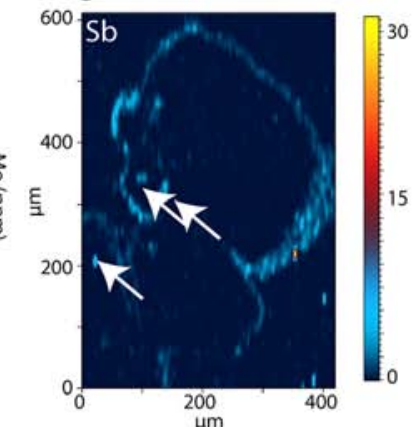

k

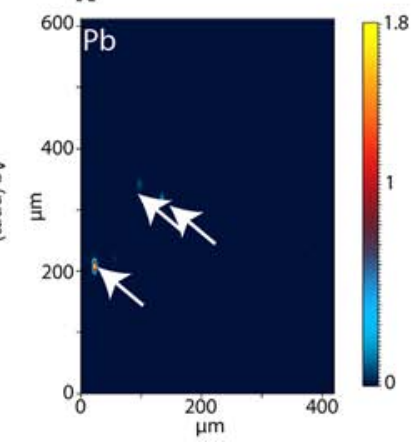

d

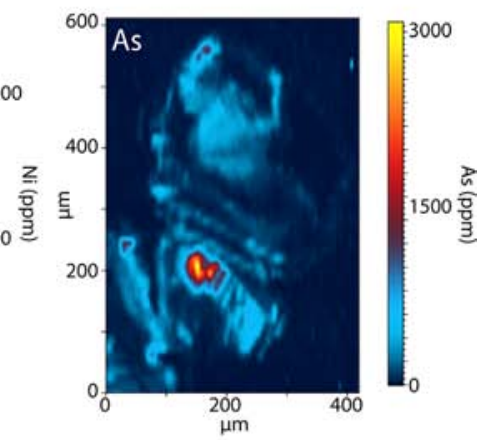

h

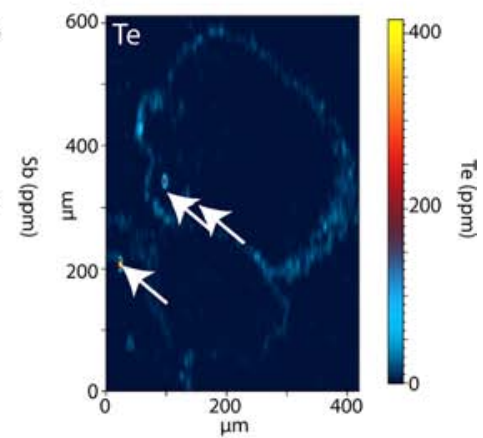

I

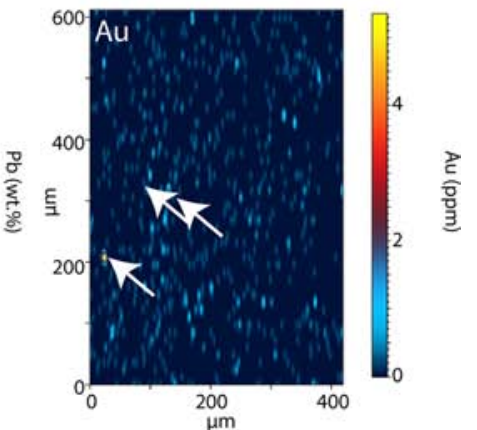

Fig. 8 Elemental maps generated with LA-ICP-MS which show the distribution of selected trace elements in py 2 aggregate in silicate facies BIF from the Meadowbank deposit. a Reflected light photomicrograph of the

distinct elemental associations with Au are clearly seen, thus confirming the presence of two distinct gold events in this sample.

Finally, a grain representing the latest stage of the pyrite paragenesis (py3), in this case present along a chert band in the oxidefacies BIF, was mapped (Fig. 10). The grain shows variable and isolated enrichment in $\mathrm{Co}, \mathrm{Ni}, \mathrm{Pb}$, and $\mathrm{Bi}$ (Fig. 10), as was previously noted for this stage of pyrite in Fig. 6. Due to the small size of the grain mapped, there is much less time-slice domain data available to be plotted compared to the previous two samples with these results summarized in Fig. 11. The latter figure shows elemental distributions and associations that suggest this pyrite has chemical affinities with the field defined for metamorphic/hydrothermal orogenic-type pyrite. In addition, we note that this pyrite is largely

mapped py2 grains disseminated in chert bands. b-I Element maps plotted as concentrations scaled between the data median $+/-3$ standard deviations. The white arrows represent inclusions

metal-poor $(\mathrm{Au}<0.3 \mathrm{ppm})$ despite the local presence of galena inclusions as suggested by sporadically high $\mathrm{Pb}$ values (Fig. 11c). In addition, in contrast to py2, py3 does not appear to have been formed from coupled dissolution-precipitation of an earlier diagenetic pyrite based on the trend of data in Fig. 11.

\section{Implications for gold mineralization at the Meadowbank deposit}

Based on integrating petrographic observations with elemental mapping and element associations, we show that pyrite from the Meadowbank deposit, either in oxide or silicate facies BIF, is associated with gold mineralization. Two distinct 
a

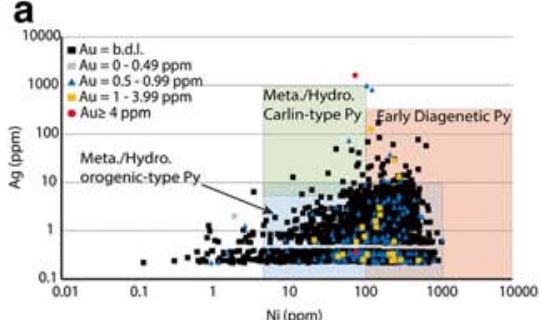

d

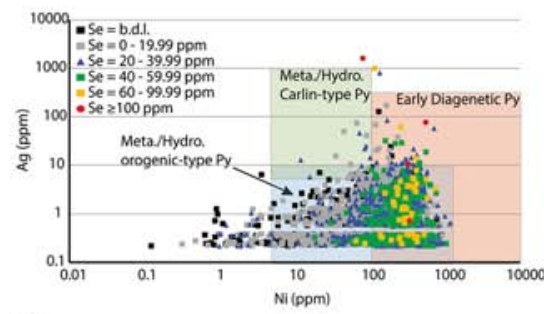

g

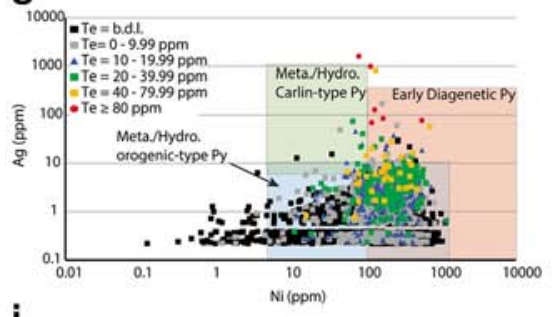

j

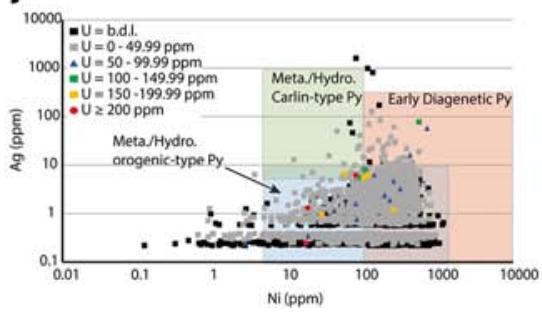

b

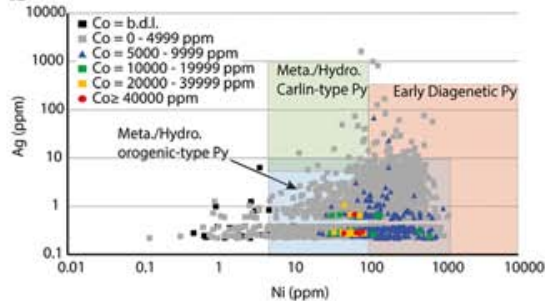

e

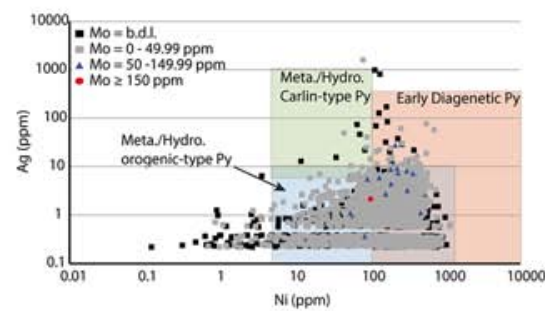

h
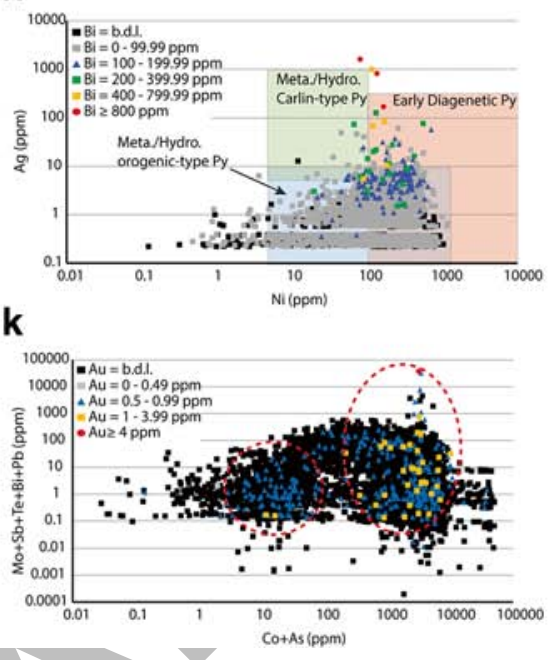

C

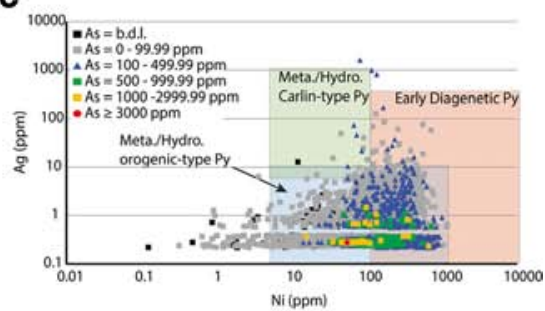

f

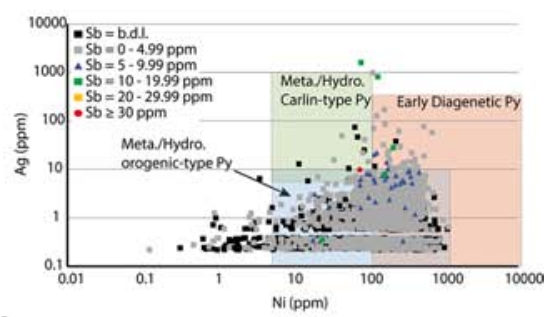

i

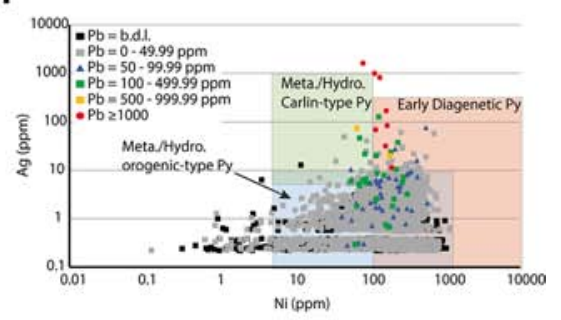

Fig. 9 Selected binary element plots (ppm) which illustrate the distribution of trace elements among py2 aggregates in silicate facies BIF (Fig. 9). $\mathbf{a}-\mathbf{j}$ Binary element plots of Ag versus Ni grouped by selected trace elements which show distribution in the previously defined pyrite fields (cf. Fig. 6). k Plot of $\Sigma(\mathrm{Mo}+\mathrm{Sb}+\mathrm{Te}+\mathrm{Bi}+\mathrm{Pb})$ versus $\Sigma(\mathrm{Co}+\mathrm{As})$ grouped by $\mathrm{Au}$ content. Note that the detection limit for $\mathrm{Ag}$ is at about $0.4 \mathrm{ppm}$ gold events are demonstrated: (1) event one is a late-stage growth of pyrite around aggregates of py 2 and shows a SeBi-Te-As-Sb-Mo elemental association (Fig. 7). This event was not recognized earlier by Janvier et al. (2015) and appears to be the most important for gold introduction and (2) event 2 which is represented by gold inclusions in py2 along with an Ag-Pb-Se-Bi-Te-As-Sb element association (Fig. 8). This event was previously recognized by Janvier et al. (2015) and considered as forming prior to $1.85 \mathrm{Ga}$ (Fig. 12). Furthermore, in both of these gold events, the observed Au enrichment does not originate from an early diagenetic, possibly framboidal type pyrite in the BIFs but instead formed from the overprinting of this pyrite related to dissolution/precipitation (py1) due to an increase in the through-put of metamorphic/ hydrothermal fluid which was likely Au-bearing.

\section{The Meliadine gold district}

\section{LA-ICP-MS trace element chemistry}

Arsenopyrite grains from the Pump and F-Zone deposits (Gourcerol et al. 2016a) were analyzed by LA-ICP-MS in traverse mode (Fig. 13 and ESM 5) with the time slide domain data for all these traverses plotted together in Fig. 14. In addition, one traverse was done across the interface of pyrrhotite included in arsenopyrite (ESM 6).

The samples are cut by several late-stage micro-fractures that show significant enrichment in various metals and indicate two distinct fracture sets: (1) one set is associated with $\mathrm{Ag}, \mathrm{Bi}$, and $\mathrm{Pb}$ enrichment combined with variable content of $\mathrm{Ni}, \mathrm{Zn}, \mathrm{Co}, \mathrm{Sb}$, and Mo; and (2) a second set is associated with 
a

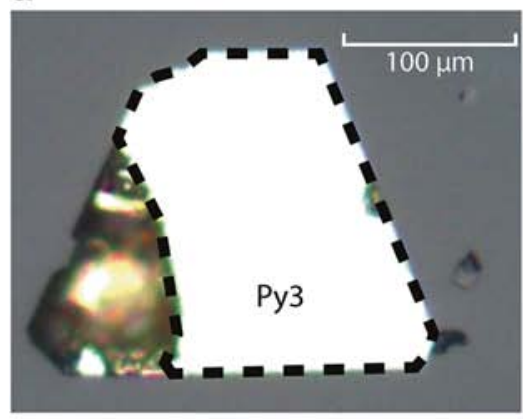

b

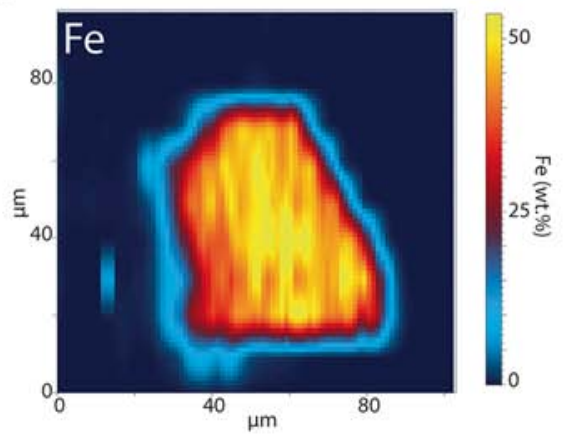

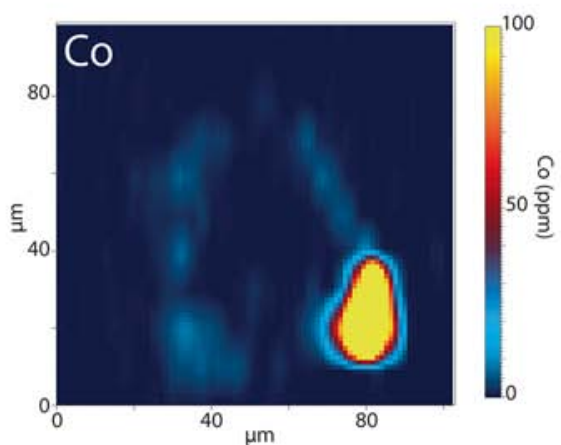

e

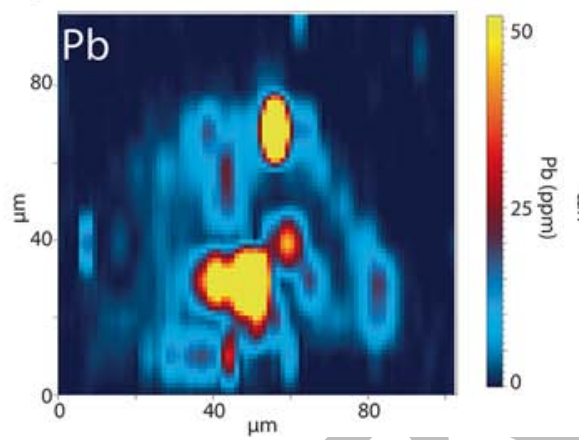

d

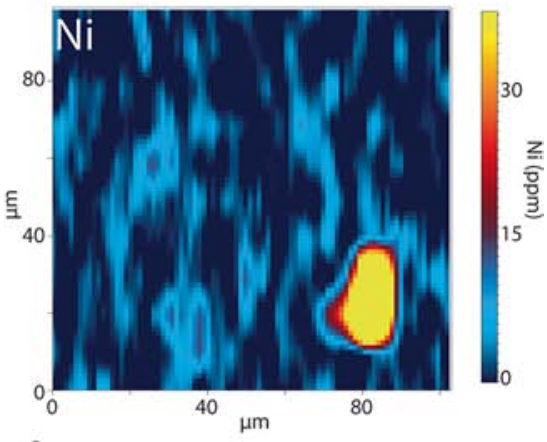

f

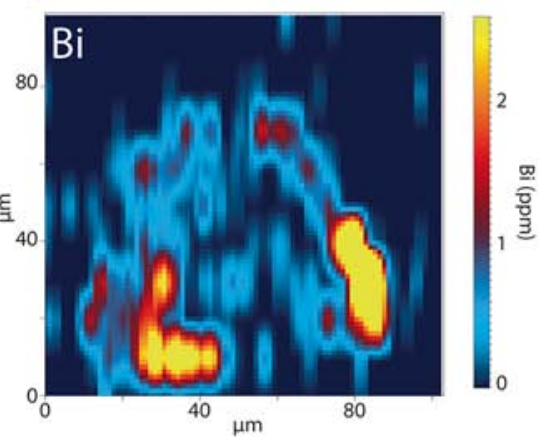

Fig. 10 Element maps generated with LA-ICP-MS which show the distribution of selected trace elements in py 3 from oxide-facies BIF from the Meadowbank deposit. a Reflected light photomicrograph of the mapped pyrite grains (py3) present in a chert band. Note that a black dashed line highlights the contour of the py3. b-f Element maps plotted as concentrations scaled between the data median $+/-3$ standard deviations

The traverse across the interface of the arsenopyritepyrrhotite reveals some interesting observations (ESM 6). Firstly, there is a marked drop in the contents of the metals shown in the pyrrhotite versus arsenopyrite, except for $\mathrm{Ni}$, which is, as expected, enriched compared to levels in both this and other arsenopyrite analyzed. Secondly, the values of most elements in this arsenopyrite are similar to those in others, but in all cases, there are marked depletion zones for all the elements at the contact with pyrrhotite. The latter feature is interpreted to indicate that the pyrrhotite is a later feature and there has been removal of elements in the arsenopyrite related to the ingress of the fluid responsible for the deposition of the chalcopyrite. The elemental associations in the various arsenopyrite grains provide insight into the timing of gold mineralization. Assuming that the Ni-Te-SeSb-Mo element association and related enrichments represent the arsenopyrite core whereas $\mathrm{Pb}-\mathrm{Bi}-\mathrm{Zn}$ enrichment represents a later fracture controlled event, it appears that only one event introduced $\mathrm{Au}$ into the system (Fig. 14a). This observation suggests the material lining these late fractures represents remobilization of invisible $\mathrm{Au}$ from the arsenopyrite lattice and precipitation of visible gold in the late fractures (Fig. 14a), which would account for the relationship of high $\mathrm{Au}$ content with elevated $\mathrm{Pb}-\mathrm{Bi}-\mathrm{Zn}$. In addition, based on element profiles (Fig. 13 and ESM 5) and selected diagrams (Fig. 14b, c), it appears that the fracture sets show 
a

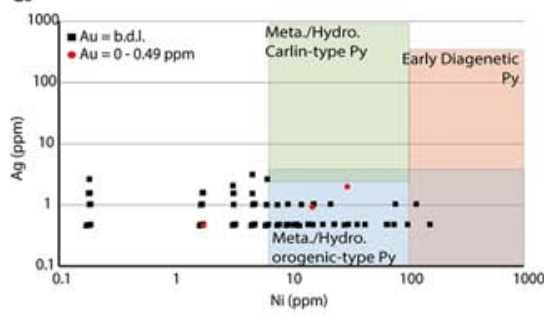

d

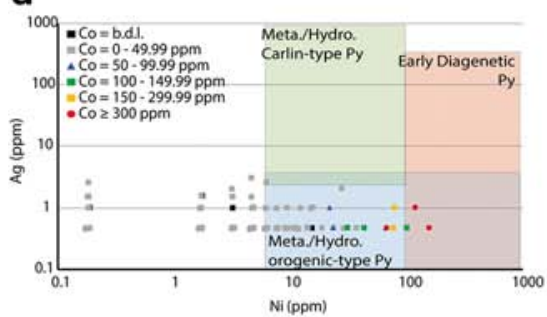

g

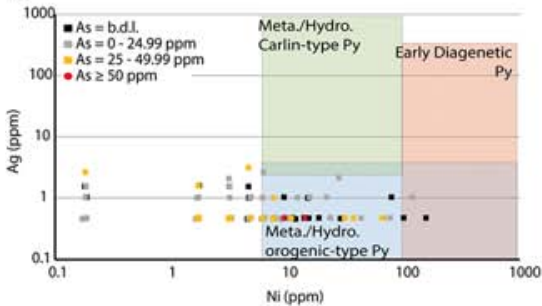

b

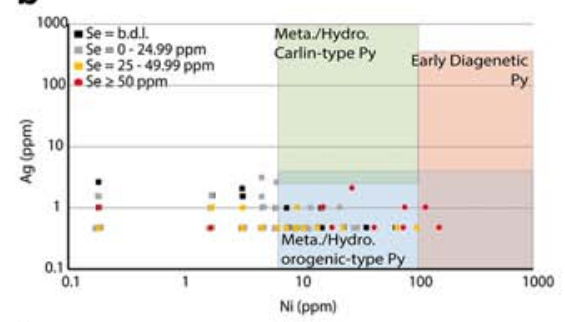

e

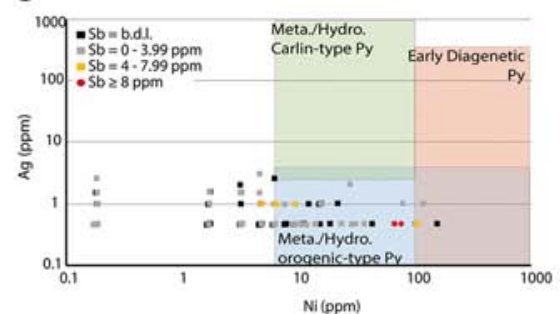

h

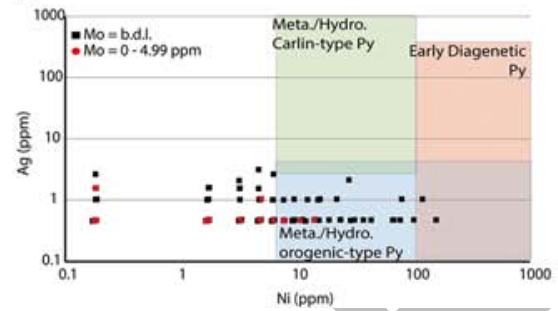

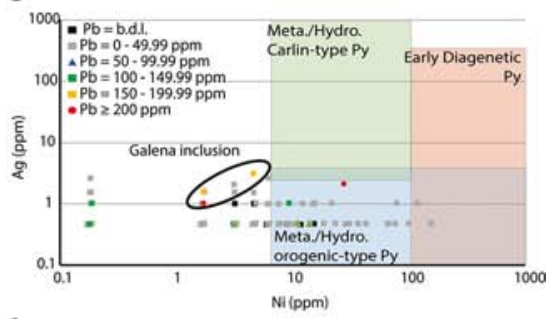

f

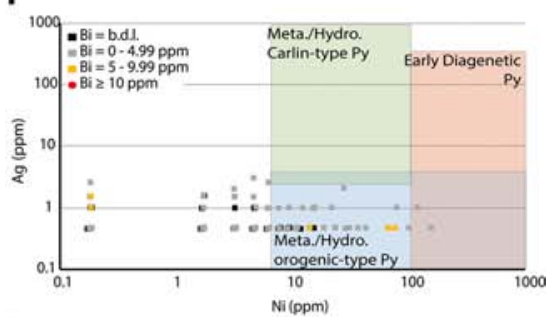

i

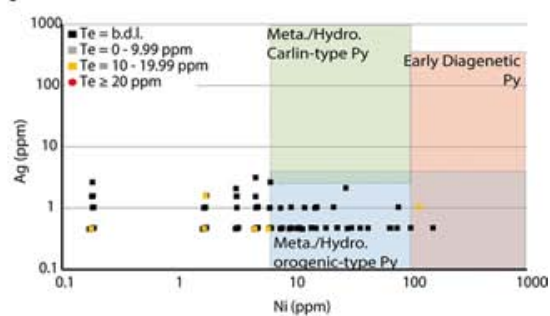

Fig. 11 Selected binary element plots (ppm) illustrating the distribution of trace elements from py3 (Fig. 11). a-i Binary element plots of $\mathrm{Ag}$ versus Ni grouped by selected trace elements, which show the distribution in the previously defined pyrite fields (cf. Fig. 6). Note that the detection limit for $\mathrm{Ag}$ is at about $0.4 \mathrm{ppm}$ multiple element associations and variable Au content: (1) enrichment of Te-Se along fractures associated with invisible gold in the sample (Fig. 14); (2) enrichment of Co along with $\mathrm{Pb}-\mathrm{Bi}-\mathrm{Zn}-\mathrm{Ag}$ in fractures associated with invisible $\mathrm{Au}$ (Fig. 14b); (3) association of $\mathrm{Pb}-\mathrm{Bi}-\mathrm{Zn}-\mathrm{Ag}$ with invisible $\mathrm{Au}$ (Fig. 14b, c); and (4) Pb-Bi-Zn-Ag associated with visible Au (Fig. 14b, c). These variable elemental associations suggest a model that involved a prolonged hydrothermal history with mobilization of earlier gold, as proposed by Lawley et al. (2015c).

Lastly, the results of elemental LA-ICP-MS mapping by Lawley et al. (2015c) on late-stage overgrowths of arsenopyrite devoid of inclusions and fractures showed this stage tends to have a Ni-Co-Te association and does not show any $\mathrm{Au}-\mathrm{Se}-\mathrm{Sb}$ enrichment compared to the first arsenopyrite grain. Although not clearly observed in our element
Fig. 12 Binary element plot (ppm) of $\mathrm{Ag}$ versus $\mathrm{Pb}$ using a compilation of individual timeslices of data from the py2 trace element maps of samples from the silicate and oxide-facies BIF

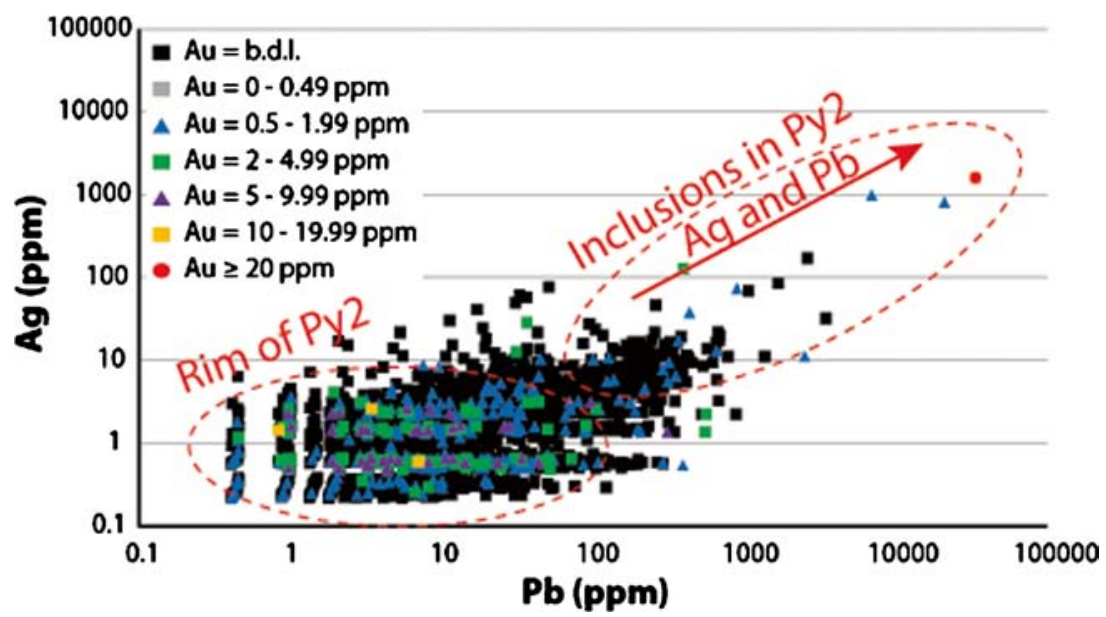



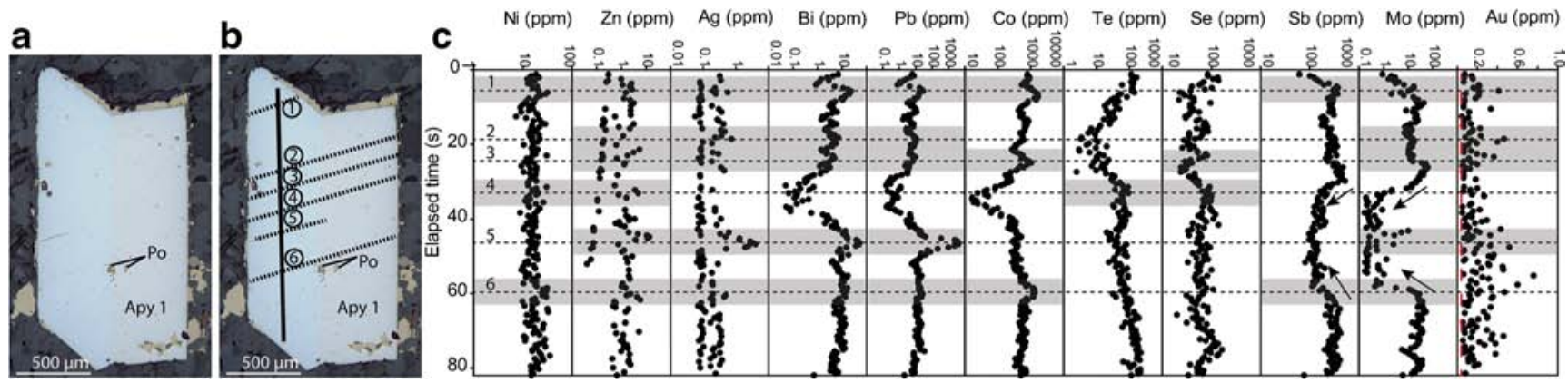

Fig. 13 Trace element profiles generated with LA-ICP-MS for a traverse done on an arsenopyrite grain from the Pump deposit (Meliadine gold district). a, b Un-annotated and annotated reflected light photomicrograph of the analyzed arsenopyrite grain. The black solid line represents the traverse whereas the dashed black lines, numbered from 1 to 6 , represent micro-fractures identified by petrographic observation. c Selected trace element profiles (ppm) for the traverse shown in $\mathbf{b}$. Note the

profiles, our compiled dataset (Fig. 14d) is consistent with this observation.

\section{Implications for gold mineralization the Meliadine gold district}

The earlier results of LA-ICP-MS elemental mapping of arsenopyrite (Carpenter 2004; Lawley et al. 2015c) suggested gold mineralization at the Meliadine deposit in the Churchill Province was related to its early introduction during the Archean growth of coarse-grained apy1 and was subsequently remobilized during subsequent deformation/metamorphism (Wagner et al. 2007) and pressure-solution processes accompanying the Trans-Hudson Orogeny (i.e., 1.86-1.85 Ga). Thus, concentration of $\mathrm{Au}$ in later stage recrystallized apy 2 and along fractures may relate to the effect of the Trans-Hudson Orogeny. These conclusions are compatible with the findings presented here which identified two mineralizing processes, one contemporaneous with initial sulfide growth and a second related to a later fluid event which infiltrated the arsenopyrite along two fracture sets. Furthermore, our data identify an elemental association of As-Ag-Bi-Pb-Se-Te with the early gold event in the mineralized BIF, whereas Bi-Mo-Te are associated with the later gold mineralization (Fig. 14e, f). The latter does not necessarily imply the introduction of new Au, but the present study also does not permit us to discount such an interpretation and further work would be required to address this interpretation.

\section{The Musselwhite deposit}

\section{LA-ICP-MS trace element chemistry}

Subhedral to euhedral pyrrhotite grains disseminated in chert bands or lining fractures in euhedral garnets (Fig. 15) display fairly similar textural features and gold-related elemental associations based on line traverses for 10 grains. Two of these line following features highlighted in the figures: (1) the dashed black lines refer to the micro-fractures; (2) the gray fields highlight areas of significant elemental enrichments; (3) the black arrows (for $\mathrm{Sb}$ and Mo profiles) indicate significant depletions; and (4) the red dashed line in the $\mathrm{Au}$ profile refers to the higher detection limit (as each data has their own detection limit). It is noted that all element concentrations except $\mathrm{Au}$ are on a logarithmic scale. Apy: arsenopyrite; Po: pyrrhotite

traverses in pyrrhotite are shown in Fig. 15 and the following comments pertain to both these traverses and the other not shown. In general, the cores of pyrrhotite show low base and precious metal contents which have been modified along late fractures, as illustrated by dashed black lines on the element profiles, and/or due to the presence of micro-inclusions. Based on petrographic and geochemical studies, it appears that only one set of the fractures observed contains significant base metal enrichment and this includes $\mathrm{Zn}, \mathrm{Pb}, \mathrm{Bi}$, and $\mathrm{As}$, variable $\mathrm{Cu}, \mathrm{Te}$, $\mathrm{Sb}$, and $\mathrm{Ag}$, along with $\mathrm{Au}$. The local presence of microinclusions is also recorded in some of the elemental profiles (Fig. 15f, g) which show erratic enrichment of $\mathrm{Cu}, \mathrm{Zn}, \mathrm{Se}$, and $\mathrm{Ag}$, variable Te and $\mathrm{As}$, and enrichment of $\mathrm{Au}$. In both cases, this $\mathrm{Au}$ enrichment is presumed to be present as micro-grains given they are not observed optically or with the SEM. Considering the $\mathrm{Cu}-\mathrm{Ag}-\mathrm{Te}-\mathrm{Se}$ element association with the Au-rich inclusions and elevated $\mathrm{Pb}-\mathrm{Bi}$ in late Au-rich fractures, a compilation of individual time-slice data from 10 line traverses of pyrrhotite grains suggests there was only a single gold event (Fig. 16). The distribution of data in the latter diagram suggests Au may have been initially bound in a pre-existing sulfide phase such as pyrite, subsequently replaced by metamorphic pyrrhotite (as suggested in the paragenesis sequence above) and later remobilized into fractures by base-metal-bearing fluids ( $\mathrm{Pb}, \mathrm{Bi}$; Fig. 16).

A single line traverse done on an arsenopyrite grain detected significant contents of $\mathrm{Au}$ (below detection limit (b.d.l.) to $11,000 \mathrm{ppm}$ ), which may illustrate a later stage sulfide event given that arsenopyrite is seen to locally overprint the pyrrhotite (Fig. 17). The subhedral to euhedral arsenopyrite has a possible core zone relatively enriched in metals, such as $\mathrm{Zn}, \mathrm{Ni}, \mathrm{Sc}, \mathrm{Sb}$, Se, and Te (Figs. 17 and 18), which is cut by several microfractures that are also enriched in base and precious metals such as $\mathrm{Zn}, \mathrm{Pb}, \mathrm{Bi}, \mathrm{Te}, \mathrm{Se}, \mathrm{Ag}$, and $\mathrm{Au}$ with variable $\mathrm{Sb}$. The latter element association a single set of fractures (Fig. 17), but it shows a significant $\mathrm{Au}$-rich along with $\mathrm{Ag}, \mathrm{Te}$, and variable $\mathrm{Cu}, \mathrm{Zn}, \mathrm{Bi}$, and $\mathrm{Pb}$ enrichments. The time-slice data for 

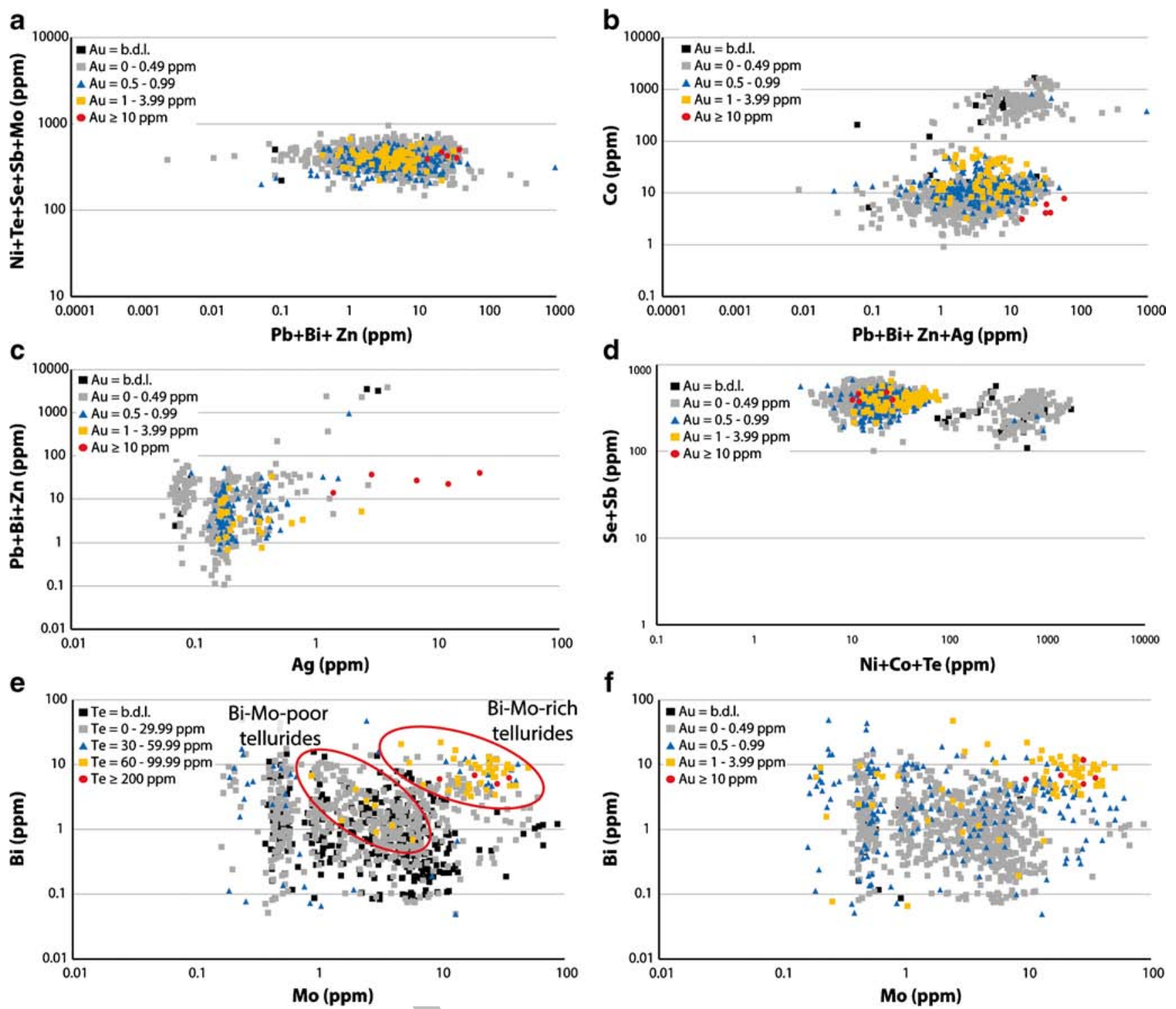

Fig. 14 Selected binary plots (in ppm) illustrating the distribution of $\mathrm{Au}$ and $\mathrm{Te}$ in various element associations from the compilation of traverse analyses done on arsenopyrite grains from the Meliadine gold district. a Binary plot of $\Sigma(\mathrm{Ni}+\mathrm{Te}+\mathrm{Se}+\mathrm{Sb}+\mathrm{Mo})$ versus $\Sigma(\mathrm{Pb}+\mathrm{Bi}+\mathrm{Zn})$ grouped by $\mathrm{Au}$ content. b Binary plot of Co versus $\Sigma(\mathrm{Pb}+\mathrm{Bi}+\mathrm{Zn}+\mathrm{Ag})$. Note that the

the single line traverse suggests the presence of Ag-rich tellurides closely associated with the fracture set, as illustrated by a $\mathrm{Zn}-\mathrm{Pb}-$ Bi element association (Fig. 18a, b). In addition, Ag-Au-rich tellurides occur mainly as inclusions in arsenopyrite (Fig. 18ac) along with the highest Au and Ag concentrations (Fig. 18c, d).

\section{Implications for gold mineralization the Musselwhite deposit}

The LA-ICP-MS trace element data and petrographic observations indicate metamorphic pyrrhotite is associated with gold mineralization and has a Cu-Ag-Te-Se-(As) element association, as was also noted by Oswald et al. (2015). This event

areas enriched in $\mathrm{Au}$ are depleted in Co and near fractures. $\mathbf{c}$ Binary plot of $\Sigma(\mathrm{Pb}+\mathrm{Bi}+\mathrm{Zn})$ versus $\mathrm{Ag}$ grouped by Au content. $\mathbf{d}$ Binary plot of Se+ $\mathrm{Sb}$ versus $\Sigma(\mathrm{Ni}+\mathrm{Co}+\mathrm{Te})$ grouped by $\mathrm{Au}$ content. e Binary plot of $\mathrm{Bi}$ versus Mo grouped by Te content. f Binary plot of Bi versus Mo grouped by Au content

appears to reflect the main gold event in this deposit. However, our additional data also reveal remobilization of the early gold which is clearly seen by the elevated Au associated with fractures cutting pyrrhotite. In addition, the of At in paragenetically later arsenopyrite (i.e., to $1000 \mathrm{ppm} \mathrm{Au}$ ) indicates the presence of an additional gold event which was not reported by previous workers. Thus, gold mineralization associated with the first gold event occurs on fractures in pyrrhotite and is related to a remobilization by a fluid which also carries $\mathrm{Pb}$ and $\mathrm{Bi}$. In addition, we also note the presence of a second, albeit lesser in significance, gold event recorded in later arsenopyrite which also has a different geochemical signature than the first one, this being an $\mathrm{Ag}$-Te element association. 


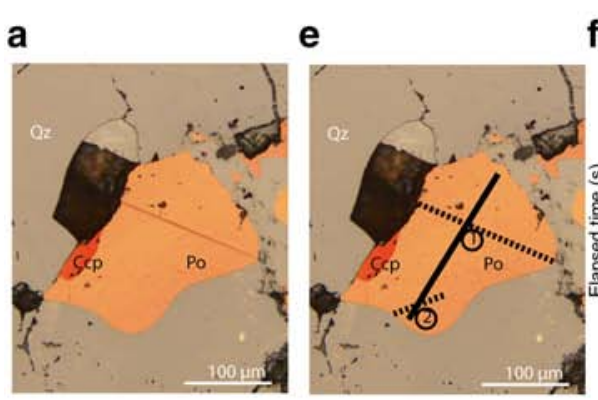

$\mathrm{Cu}(\mathrm{ppm}) \quad \mathrm{Zn}(\mathrm{ppm}) \quad \mathrm{Pb}(\mathrm{ppm}) \quad \mathrm{Bi}(\mathrm{ppm}) \quad \mathrm{Sb}(\mathrm{ppm}) \quad \mathrm{Te}(\mathrm{ppm}) \quad \mathrm{As}(\mathrm{ppm}) \quad \mathrm{Ag}(\mathrm{ppm}) \quad \mathrm{Au}(\mathrm{ppm})$

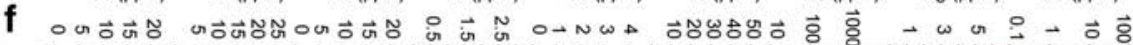

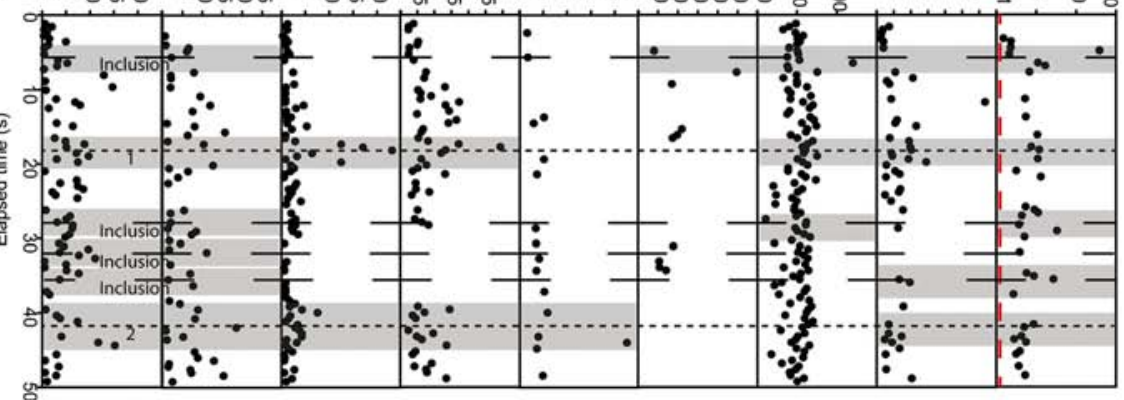

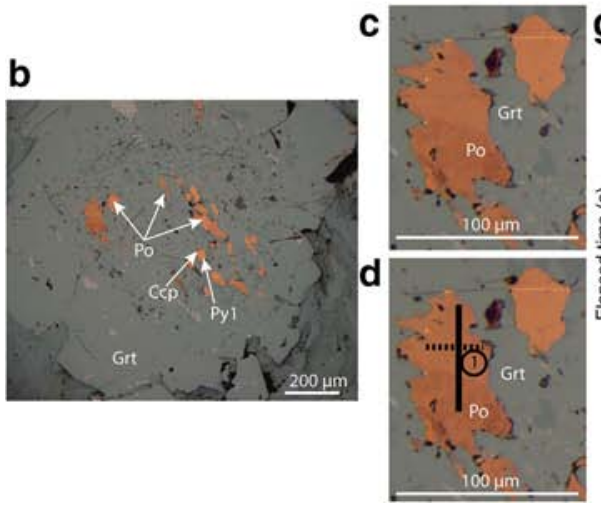

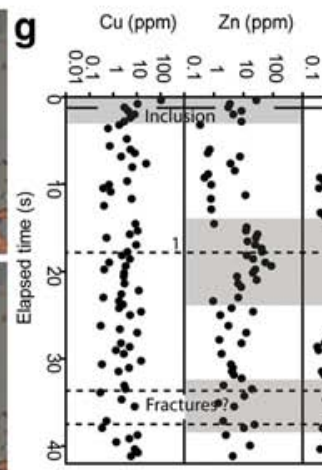

Fig. 15 Trace element profiles generated with LA-ICP-MS for two traverses done on disseminated pyrrhotite grains from the Musselwhite deposit. a-c Reflected light photomicrograph of the analyzed pyrrhotite. d, e Annotated reflected light photomicrograph of the analyzed pyrrhotite along with local chalcopyrite inclusion. The black solid line represents the traverse whereas the dashed black lines, numbered from 1 to 2 , represent micro-fractures as seen in petrographic study. f, $\mathbf{g}$ Selected trace element

\section{Discussion}

In this study, three Canadian BIF-hosted gold deposits (Meadowbank, Meliadine, and Musselwhite) were selected for detailed in situ LA-ICP-MS elemental mapping and traverses analyses of sulfide phases (pyrite, arsenopyrite, pyrrhotite) in order to assess potential sources for mineralizing fluids,

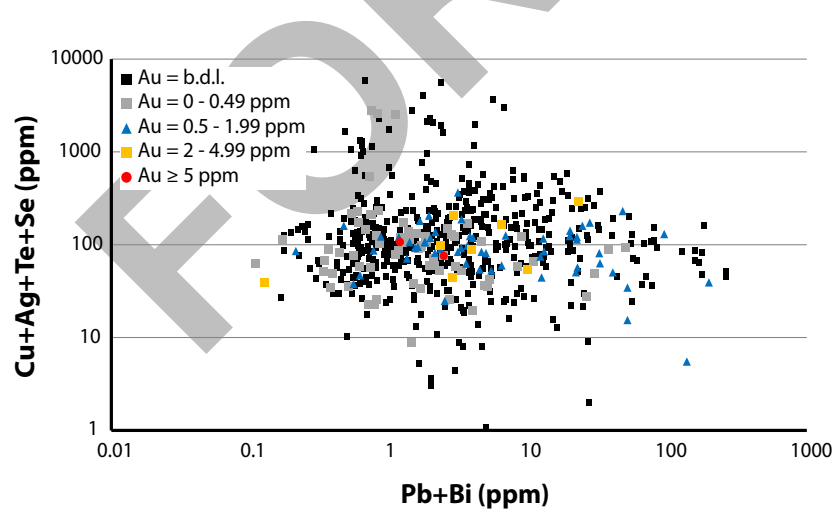

Fig. 16 Binary plot (in ppm) of $\Sigma(\mathrm{Cu}+\mathrm{Ag}+\mathrm{Te}+\mathrm{Se})$, representing $\mathrm{Au}-$ related element association in the pyrrhotite core, versus $\Sigma(\mathrm{Pb}+\mathrm{Bi})$, which represents an $\mathrm{Au}$ element association in the pyrrhotite fractures, using a compilation of individual time-slices of data from the pyrrhotite trace element traverse of 10 pyrrhotite samples profiles (concentrations in ppm) for the traverse shown in $\mathbf{d}$ and e. Note the following features highlighted in the figures: (1) the closely spaced dashed black lines refer to micro-fractures observed in the previous image, the more spaced dashed black lines refer to possible inclusions; (2) the gray fields highlight areas of significant elemental enrichment; and (3) the red dashed line in Au profile refers to the higher detection limit. Ccp: chalcopyrite; Grt: garnet; Po: pyrrhotite; Py: pyrite; Qz: quartz

define elemental associations, identify the relative timing of metal and sulfide enrichment event(s), and to constrain the gold enrichment processes.

The complexity in element associations documented here for nominally similar BIF-hosted gold deposits is a function of (1) element coupling and decoupling; (2) elemental paragenesis; and (3) the nature of reactivation or overprinting events in orogenic deposits (e.g., Kontak, 2015). The complexity in mineral geochemistry in hydrothermal ore systems is furthermore consistent with the longevity of the gold-related mineralizing systems (e.g., Kontak 2015). As summarized below, the stratigraphic associations within the mineralized greenstone belt and the gold source are additional parameters affecting the chemical signal recorded within the studied sulfides.

\section{LA-ICP-MS method and implications for identifying gold events and their chemical signature}

Trace element distribution maps, as well as traverse analyses, reported herein were determined using the LA-ICP-MS method on carefully selected and petrographically characterized pyrite, arsenopyrite, and pyrrhotite. The method provides 


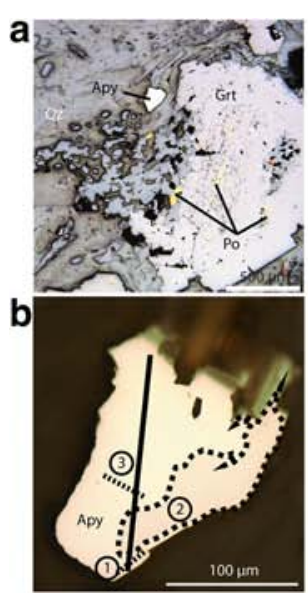

C

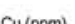

Bi (ppm)

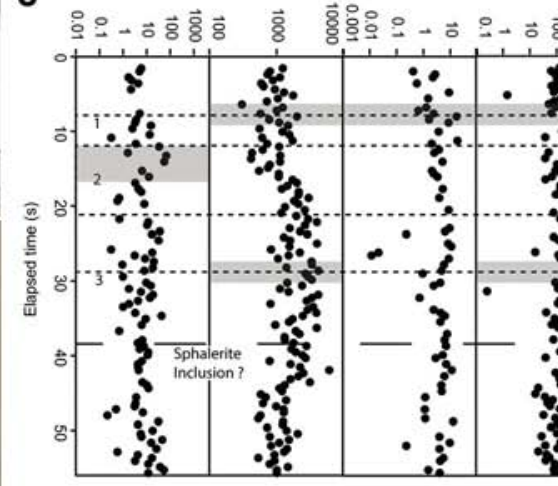

Fig. 17 LA-ICP-MS trace element profiles for a traverse done on an arsenopyrite grain from the Musselwhite deposit. a Reflected light photomicrograph of pyrrhotite, arsenopyrite, and chalcopyrite inclusions along fractures in garnet grain disseminated in chert. b Close up of an arsenopyrite grain. The black solid line represents the traverse whereas the dashed black lines, numbered from 1 to 3 , represent microfractures. c Selected trace element profiles (ppm) for the traverse shown in

meaningful information as to the distribution of major, minor, and trace elements in sulfides which can be related to their growth history using the maps or profiles generated. In addition, the integration of this information with plots generated using the time-slice domains protocol provides the means to b. Note the following features highlighted in the figures: (1) the closely spaced dashed black lines refer to micro-fractures observed in the previous image, the more spaced dashed black line refers to possible sphalerite inclusion; (2) the gray fields highlight areas of significant elemental enrichment; and (3) the red dashed line in the Au profile refers to the higher detection limit. It is noted that all element concentrations are on a logarithmic scale. Apy: arsenopyrite; Grt: garnet; Po: pyrrhotite; Qz: quartz

evaluate the data in terms of multi-dimensional chemical associations.

The major advantage of LA-ICP-MS mapping and timeresolved traverses is that the data generated provides the means to recognize element associations as well as their a

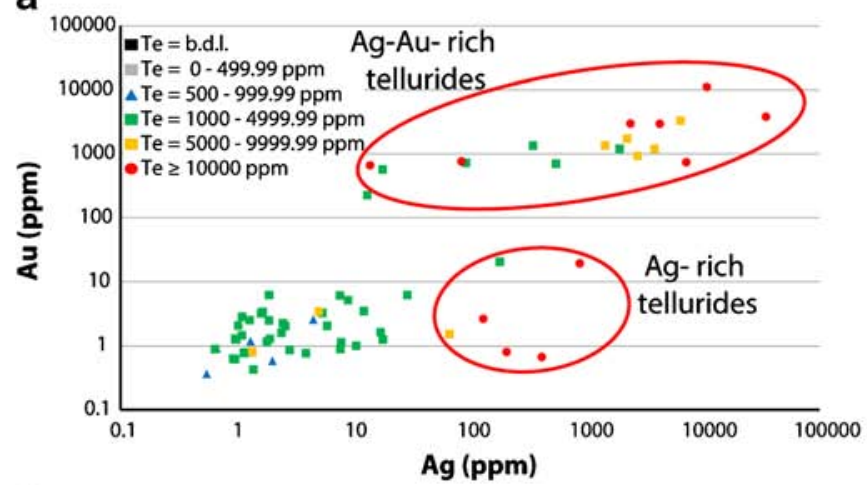

c

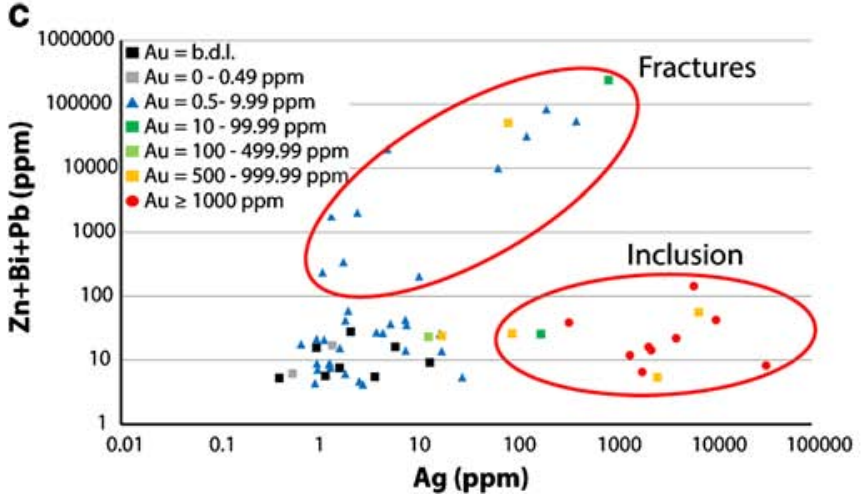

Fig. 18 Selected binary plots (ppm) showing the distribution of Au and $\mathrm{Te}$ from the arsenopyrite data. Note that the data are also grouped by color according to their $\mathrm{Au}$ and $\mathrm{Te}$ contents. a Binary plot for $\mathrm{Au}$ versus $\mathrm{Ag}$ b

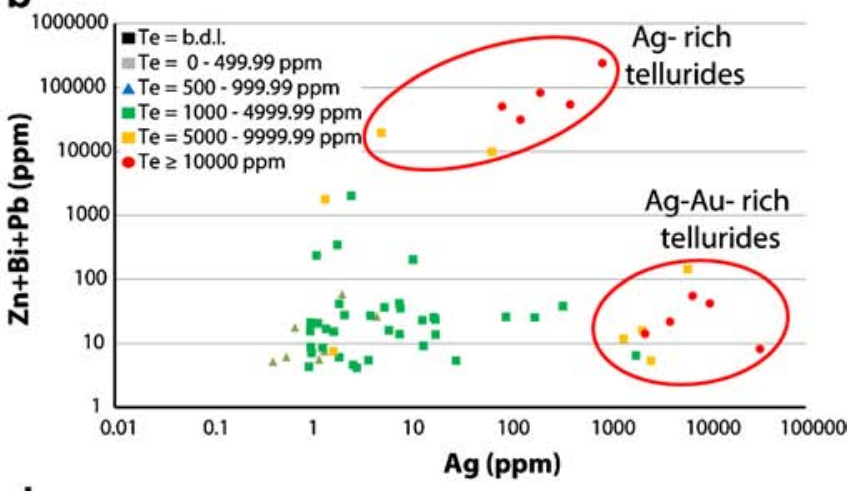

d

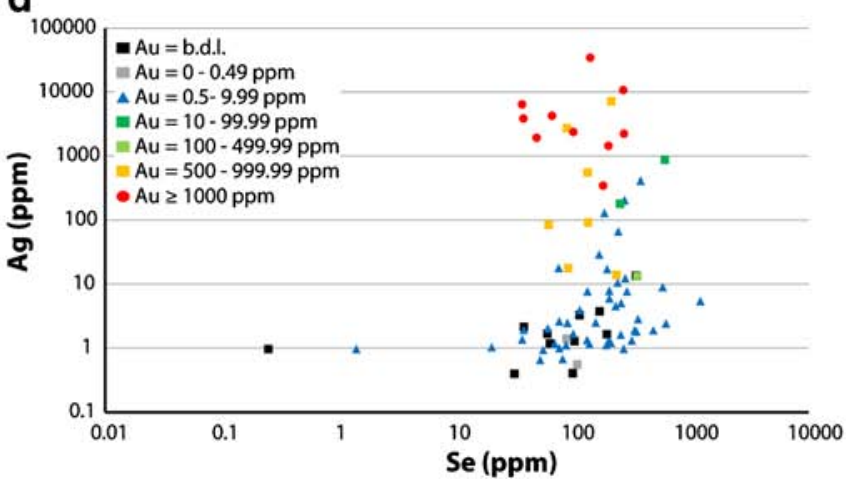

with Te content color coded. b Binary plot of $\Sigma(\mathrm{Zn}+\mathrm{Bi}+\mathrm{Pb})$ versus $\mathrm{Ag}$ with Te color coded. $\mathbf{c}$ Binary plot of $\Sigma(\mathrm{Zn}+\mathrm{Bi}+\mathrm{Pb})$ versus $\mathrm{Ag}$ with $\mathrm{Au}$ colored coded. d Binary plot of Ag versus Se with Au color coded 
spatial distribution (e.g., within fractures, as inclusions) as the laser beam scans a sample. The latter methods thus eliminate the minimizing effect that results from the averaging of element concentrations obtained using conventional analysis of either whole rock or mineral separate samples prepared for solution-based ICP-MS analysis (e.g., Janvier et al. 2015; Oswald et al. 2015). Moreover, this study shows that quantitative traverses, when combined with careful petrographic observations, provide data comparable to element distribution maps in a shorter timeframe, and importantly, at less cost (e.g., elemental mapping of arsenopyrite grains in Lawley et al. (2015c) versus line traverses of arsenopyrite grains herein (Note: although not discussed here, one of the limiting factors of LA-ICP-MS mapping is the cost, which is lab dependent). However, an observable limitation relates to the size of the laser beam (i.e., in this and other studies, it is $>9 \mu \mathrm{m}$ ) such that it is not possible to analyze very small sulfide grains. A consequence of the latter is that during rastering and traversing there is an averaging of data over small (relative to the beam diameter) inclusions and/or fractures.

Notwithstanding, a systematic compilation of time-slice datasets from LA-ICP-MS analyses (mainly from maps and traverses) provides a significant means to assess the number of gold events and their respective elemental signature which is not easily or always discernable from examining the distribution element maps and traverses (Figs. 12, 14, and 18). For instance, with the time-slice method of data treatment, several plots might be used to discriminate sulfide origins, such as the proposed Ag versus Ni plots in this study. In the latter plot, the empirically based discriminant fields constrain the possible processes of pyrite formation via coupling/decoupling processes (i.e., diagenetic versus metamorphic/hydrothermal types and dissolution/precipitation) and establishes the origin of the metals during the different types of pyrite growth (such as dissolution/precipitation). We suggest that this latter plot, combined with detailed petrographic study, should be applied routinely in future studies when pyrite from sedimentary deposits is analyzed, but it has to be used carefully as the Ag and $\mathrm{Ni}$ concentrations of pyrite may vary significantly with bulk chemistry of the host rocks (mafic versus felsic).

\section{Comparison of elemental associations and implications for source reservoirs of gold}

Two distinct gold events are present at the Meadowbank deposit, as represented by either invisible gold or micro-inclusions in the same pyrite generation (py2). The main gold mineralizing event, which is represented by the refractory gold, displays a Se-Bi-Te$\mathrm{As}-\mathrm{Sb}$ elemental association whereas the second event related to micro-inclusions has an Ag-Pb-Se-Bi-Te-As-Sb element association. The second stage pyrite (py2) is considered to originate via a dissolution/precipitation process (e.g., Putnis 2002; Putnis et al. 2007; Putnis and Putnis 2010), which affected an earlier pyrite of suggested diagenetic framboidal origin (py1). Fluids which mediated formation of the later pyrite (py2) are considered to be orogenic, that is of metamorphic/hydrothermal origin, and thus in this context can possibly be related paragenetically to the inferred formation of late-stage pyrite observed in other sedimenthosted gold deposit settings, such as at Sukhoi Log, Bendigo, and Spanish Mountain (Large et al. 2007, 2009, 2011). Analyses of the cores zones of pyrites (early stage pyrite growth) from these latter localities showed they are enriched in a variety of elements, which include $\mathrm{Mo}, \mathrm{Pb}, \mathrm{Ni}, \mathrm{Co}$, and $\mathrm{W}$. Despite evidence of early diagenetic py1, conversion into gold-hosting py2 at Meadowbank, the budget of $\mathrm{Au}$ and other accompanying elements ( $\mathrm{Se}, \mathrm{Te}, \mathrm{As}$, and some part of the $\mathrm{Ag}, \mathrm{Sb}$ ) appear to reflect the presence of an external metamorphic/hydrothermal fluid that was responsible for enriching these elements coevally with/or during the late-stage growth of py2. This observation is important as it implies that the sulfidation (replacement) of pre-existing stratabound magnetite bands at this BIF-hosted gold deposit was independent from development of py 1 and that $\mathrm{Au}$ and other related elements did not originate from their remobilization from an earlier in situ pyrite phase. Furthermore, the presence of microinclusions, which was recognized by Janvier et al. (2015), may represent subsequent remobilization via fracture networks of an earlier refractory gold event from metamorphic pyrite. That the latter event has a Se-Bi-Te-As-Sb elemental association (e.g., Wagner et al. 2007) suggests therefore that this remobilization involved $\mathrm{a} \mathrm{Pb}-, \mathrm{Ag}-$, and Bi-rich fluid.

A major gold event along with an additional later remobilization and upgrading process is recorded by arsenopyrite in the Meliadine gold district (i.e., the F-Zone and Pump deposits). The main and early gold event, which is refractory in nature, has an $\mathrm{As}-\mathrm{Ag}$-Se-Te element association, as recorded in the hydrothermal arsenopyrite. The subsequent remobilization and upgrading of $\mathrm{Au}$ are represented by the presence of either micro-inclusions or as invisible gold along fracture networks or crosscutting veins (Wagner et al. 2007). These metamorphic fluids have been characterized by having a $\mathrm{Pb}$ Bi-Se-Te signature.

Two distinct gold events at the Musselwhite deposit are associated with metamorphic pyrrhotite or late-stage arsenopyrite. The first gold event, which has a $\mathrm{Cu}-\mathrm{Ag}-\mathrm{Se}-\mathrm{Te}$ (As) element association, is represented by the presence of invisible gold and also as micro-inclusions in pyrrhotite and is the main gold event in the deposit. This observation suggests that $\mathrm{Au}$ was first introduced in an earlier pre-existing Fe sulfide phase (py1) which is now present as micro-inclusions (i.e., remnant pyrite) in metamorphic pyrrhotite. Moreover, based on the presence of base metal-enriched fracture networks in pyrrhotite, it is inferred that gold was remobilized into fracture sets by a later metal-rich metamorphic fluid $(\mathrm{Cu}-, \mathrm{Zn}-, \mathrm{Bi}-$, and $\mathrm{Pb}$ bearing fluid). Finally, a second gold event, which is present in the paragenetically later arsenopyrite, exhibits an Ag-Te element association, which suggests that arsenopyrite is related 
to a relatively late gold mineralization event. This latter conclusion contrasts with the conclusions of Oswald et al. (2015) who suggested that arsenopyrite did not correlate with $\mathrm{Au}$ grades, although we note that the latter may in fact in part relate to the abundance of arsenopyrite in samples analyzed.

The three BIF-hosted gold deposits though located in different cratons, exhibit similar gold mineralizing processes: (1) an early introduction of Au with an Au-As-Se-Te-Ag association and (2) a later stage remobilization event whereby $\mathrm{Au}$ is deposited along fracture networks by metamorphic fluids that have a ( $\mathrm{Ag})-\mathrm{Pb}-\mathrm{Bi}$ signature. This observation has been noted for pyrite, pyrrhotite, and arsenopyrite. Moreover, the early gold event in each of the three deposits appears to have been introduced by an external fluid rather than locally sourced in for example a diagenetic sulfide such as framboidal pyrite. The similarity of element associations for this early gold event among the different deposits also confirms an epigenetic origin for gold in these deposits and may suggest a common source from which these elements were leached and subsequently channeled via structural conduits (such as faults, shear zones) into higher crustal levels. Of particular relevance, here is the analogous BIF-hosted Homestake gold deposit which shows a similar $\mathrm{Au}$-trace element association (AuAg-As-Te-Se; Caddey et al. 1991; Morelli et al. 2010; Steadman and Large 2016).

Regarding the probable source of the constituent elements, Pitcairn et al. (2006) pointed out that $\mathrm{Au}, \mathrm{Ag}$, As, and Se are found in significantly lower concentrations in stratigraphically equivalent metasedimentary rocks of higher metamorphic rank compared to their unmetamorphosed equivalents. Thus, similar weakly to unmetamorphosed similar sedimentary rocks might also have been source for the main gold mineralization in the Algoma-type BIFs. However, we also note that there are many potential source reservoirs for gold in orogenic-type deposits, including mafic volcanic rocks in some settings, and constraining their origin is challenging due to the equivocal nature of the fluid chemistry (McCuaig and Kerrich 1994, 1998; Ridley and Diamond 2000; Groves et al. 2003; Goldfarb et al. 2001, 2005; Pitcairn et al. 2006; Goldfarb and Groves 2015). Based on our limited number of analyses, the results of this study do not, however, advocate extraction of $\mathrm{Au}$ and other metals from gold-rich diagenetic pyrite, as has been argued for several sediment-hosted orogenic gold deposit settings by Large et al. (2007, 2009, 2011). Our reasoning is that elemental mapping of inferred framboidal pyrite in the Central BIF from the Meadowbank deposit indicates a lack of significant $\mathrm{Au}$ content. We do note however that such a conclusion is tenuous based on both interpretation of the texture preserved in the sample and the limited amount of such material analyzed; further work is needed to better resolve this issue. Having said this we also note that there is a lack of any $\mathrm{Au}$ association with the specific suite of elements ( $\mathrm{Co}, \mathrm{Ni}, \mathrm{Pb}, \mathrm{Zn}, \mathrm{W}, \mathrm{Mo}$ ) that are generally noted to be highly concentrated in diagenetic pyrite (Fig. 6). Furthermore, a similar argument is made based on data the Meliadine gold district and Musselwhite deposit where in fact there is a lack of evidence for an early diagenetic type pyrite which may have been enriched in Au. Finally, the second gold event reported here for the Musselwhite deposit does not share either geochemical or mineralogical similarities with the other deposits studied in that this gold event is characterized by an $\mathrm{Au}-\mathrm{Ag}-\mathrm{Te}$ association. As explained previously, this later event may reflect the ingress of a new, external fluid carrying Au-Ag-Tewhich suggests a different fluid source than the first event and a different gold enrichment process. This mineralizing event seems, however, to represent a minor part of the Musselwhite deposit relative to first gold event.

\section{Influence of the regional stratigraphy}

Although the three desitudies share some similarities regarding their potential fluid sources and timing of the main gold event, significant differences also exist as to which sulfides are auriferous: pyrite in Meadowbank, arsenopyrite in Meliadine, and pyrrhotite in Musselwhite. This difference in the repository for gold may be influenced by the stratigraphy with which Au-bearing fluids reacted along their flow path. For instance, formation of arsenopyrite requires As (e.g., Kretschmar and Scott 1976), which may in some cases be sourced from local sedimentary wallrocks (Kontak and Smith 1993; Bierlein and Crowe 2000; Thomas et al. 2011). The fact that there is a higher proportion of metasedimentary rocks in the Meliadine gold district compared to both the Meadowbank and Musselwhite deposit areas is consistent with this interpretation. Furthermore, the influence of stratigraphy is also reflected by the elemental budget in the sulfides. For instance, pyrrhotite associated with gold mineralization at the Musselwhite deposit is highly enriched in $\mathrm{Ni}$ (to $8100 \mathrm{ppm}$ ), Co (to $1000 \mathrm{ppm}$ ), and Pd (to $190 \mathrm{ppm}$ ) relative to pyrrhotite from the Meliadine gold district $(\mathrm{Ni}<430 \mathrm{ppm}$; $\mathrm{Co}<120 \mathrm{ppm} ; \mathrm{Pd}<0.5 \mathrm{ppm}$ ). If it is assumed that pyrrhotite at these different settings had the same capacity to sequester (partition) the aforementioned elements, then it might be inferred that their varying elemental enrichment lies in the different elemental budgets of the fluids. This reasoning may suggest therefore that the mineralizing fluids at the former deposit equilibrated to some extent with an ultramafic-mafic component in the stratigraphy and was relatively enriched in these metals $(\mathrm{Ni}, \mathrm{Co}, \mathrm{Pd})$ through the breakdown of sulfide of presumably magmatic origin. Coincidently, the latter potential source rocks are in fact prominent at Musselwhite but not at Meliadine. Again, the geology of the settings is consistent with this interpretation (Biczok et al. 2012; Oswald et al. 2015). We also suggest here that as the database for sulfides in such settings increases, via more extensive elemental mapping and analyses as presented herein, it may become more 
apparent as to what the role and influence of the underlying stratigraphy is in ore systems. This does not, however, diminish the important differences noted here for the three deposits studied.

\section{Influence of late deformation and metamorphism}

The influence of post-ore processes such as deformation and metamorphism is an important issue in gold deposits with respect to whether new gold is introduced or pre-existing Au is remobilized internally (e.g., Wagner et al. 2007). At two of the deposits studied (Meliadine and Musselwhite), there is evidence that later stage events have partially remobilized Au originally concentrated within the lattice of the host sulfide (arsenopyrite and pre-existing pyrrhotite), as indicated by the Au-base metal association along fracture networks. This process resulted in re-concentrating $\mathrm{Au}$ either as visible native gold or an invisible component (i.e., refractory) of sulfide grains. However, based on our observations, the majority of gold in all three deposits was primarily deposited by the first event and subsequent remobilization and upgrading events were minor or not significant to the overall Au budget.

Such remobilization and upgrading of gold is a well-known phenomenon and been studied in several gold mineralized deposit types, including gold-rich VHMS (e.g., Wagner et al. 2007), sediment-hosted gold (e.g., Large et al. 2007, 2009), and orogenic gold (Tomkins et al. 2004). In these studies, the authors refer to a closed-system metamorphic event with $\mathrm{Au}$ internally redistributed. In contrast, for the Meliadine and Musselwhite deposits, the element associations of the metalbearing fluids, which are $\mathrm{Pb}-\mathrm{Bi}-\mathrm{Zn}$ and $\mathrm{Pb}-\mathrm{Bi}-\mathrm{Cu}-\mathrm{Zn}$, respectively, suggest that a similar pathway or reservoir is reflected in the fluid chemistry. Contrary to element associations with $\mathrm{Au}$, such as Ag and As, the base metals do not exhibit variations related to metamorphic grade (Pitcairn et al. 2006) and may therefore represent weak sub-greenschist to amphibolite facies conditions. Furthermore, as pointed out by Lawley et al. (2015c), Au remobilization is not developed or enriched to the same extent as the original gold mineralizing event at the Meliadine gold district; hence, the original nature of the primary event is retained.

\section{Conclusions}

\section{Quantitative in}

LA-ICP-MS element distribution analyses integraled witn petrographic and SEM studies on pyrite, arsenopyrite, and pyrrhotite from three Canadian Algoma-type BIFhosted gold deposits revealed the presence of multiple gold event(s)/remobilization processes as well as the respective element associations for each of event at these deposits. This study confirms the epigenetic origin of the main gold event in the BIF-hosted gold deposits and supports a model whereby metamorphic/hydrothermal processes related to broad orogenic events were responsible for the devolatilization of a common source reservoir. The latter process resulted in the source rock liberating Au-bearing fluids along with a specific element suite (As-Se-Te-Ag) which were subsequently channeled into Algoma-type BIF strata at higher crustal levels via major crustal faults and/or shear zones. Due to their high iron content, BIF acts as favorable chemical traps whereby it reacts with the Au-bearing fluid and through its sulfidation of pre-existing Fe-rich material leads to gold mineralization. Moreover, these new data reveal that stratigraphy contributes to the fluid chemistry and influences the nature of the sulfide phases hosting gold (arsenopyrite versus pyrite).

Beyond the metallogenic aspect, this paper also presents a novel method (i.e., the time-slice domain data) for presenting data acquired from LA-ICP-MS element mapping. Data acquired from the element distribution maps, as well as traverses and to a lesser extent spot mode analyses, provide the basis for evaluating the spatial distribution of major, minor, and trace elements and allows detection of element associations through the various stages of sulfide growth, textural development, and paragenesis (early versus late). Compilation of individual time-slice datasets thus provides a significant means to assess the number of gold events and their respective elemental signatures, which are not otherwise easily discernable through the isolated study of the elemental distribution maps. Moreover, traverse analyses integrated with detailed petrographic study provide observations similar to maps in a shorter time frame. Finally, the innovative use of $\mathrm{Ag}$ versus $\mathrm{Ni}$ plots, which are empirically based, combined with data from Large et al. (2009) provides discriminatory fields which are then applied to pyrite from sedimentary-hosted gold deposits such as $\mathrm{BIF}_{\mathbf{A}}$ constraining the origin of the elements present.

Acknowledgements The authors gratefully acknowledge the staff of Agnico Eagle Mines Ltd. and Goldcorp Ltd. and more particularly the regional exploration crews from the Meadowbank, Meliadine, and Musselwhite deposits. The study is supported by both TGI-4 funding from Natural Resources Canada and funding through a Natural Sciences and Engineering Research Council Collaborative Research and Development agreement with participation by Agnico Eagle Mines Ltd. and Goldcorp. We also thank Drs. R.R. Large and D.L. Huston for their constructive comments that helped to substantially improve the manuscript, in particular the clarity of concepts presented.

\section{References}

Agnico Eagle Ltd (2012a) Meadowbank project exploration compilation and best targets in the mine area. Prepared by Côté-Mantha O, Scale 1:50 000

Agnico Eagle Ltd (2012b) Meliadine gold district compilation. Prepared by Côté-Mantha O, Scale 1:20 000

Armitage AE, James RS, Goff SP (1996) Gold mineralization in Archean banded iron formation, Third Portage Lake area, Northwest Territories, Canada. Explor Min Geol 5:1-15 
Aspler LB, Chiarenzelli JR (1996) Stratigraphy, sedimentology and physical volcanology of the Henik Group, central Ennadai-Rankin greenstone belt, Northwest Territories, Canada: Late Archean paleogeography of the Hearne Province and tectonic implications. Precambrian Res 77(1-2):59-89. https://doi.org/10.1016/03019268(95)00045-3

Biczok J, Hollings P, Klipfel P, Heaman L, Maas R, Hamilton M, Kamo S, Friedman R (2012) Geochronology of the North Caribou greenstone belt, Superior Province Canada: implications for tectonic history and gold mineralization at the Musselwhite mine. Precambrian Res 192195:209-230. https://doi.org/10.1016/j.precamres.2011.10.012

Bierlein FP, Crowe DE (2000) Phanerozoic orogenic lode gold deposits. Rev Econ Geol 13:103-139

Bolhar R, Van Kranendonk MJ, Kamber BS (2005) A trace element study of siderite-jasper banded iron formation in the $3.4 \mathrm{Ga}$ Warrawoona Group, Pilbara Craton - formation from hydrothermal fluids and shallow seawater. Precambrian Res 137(1-2):93-114. https://doi. org/10.1016/j.precamres.2005.02.001

Breaks FW, Osmani IA, DeKemp EA (2001) Geology of the North Caribou Lake area, northwestern Ontario. Ontario Geol Survey, Open File Report pp 6023:80

Bull SW, Large RR (2015) Setting the stage for the genesis of the giant Bendigo ore system. In: Jenkin GRT, Lusty PAJ, McDonald I, Smith MP, Boyce AJ,Wilkinson JJ (eds) Ore deposits in an evolving earth, vol. 393 Geological Society, Special Publications, London, pp 1-31

Caddey SW, Bachman RL, Campbell TJ, Reid RR, Otto RP (1991) The Homestake gold mine, an Early Proterozoic iron-formation-hosted gold deposit, Lawrence County, South Dakota. United States Geol Survey 1857-J: J1-J67

Carpenter RL (2004) Relative and absolute timing of supracrustal deposition, tectonothermal activity and gold mineralization, West Meliadine region, Rankin Inlet greenstone belt, Nunavut, Canada. $\mathrm{PhD}$ Thesis. Univ Western Ontario, pp. 362

Carpenter RL, Duke NA, Sandeman HA, Stern R (2005) Relative and absolute timing of gold mineralization along the Meliadine Trend, Nunavut, Canada; evidence for Paleoproterozoic gold hosted in an Archean greenstone belt. Econ Geol 100:567-576

Cave B, Large RR, Craw D (2015) A shallow metamorphic source for tungsten (scheelite) in the turbidite hosted orogenic gold deposits of the Otago Schist, New Zealand. World-class ore deposit: discovery to recovery, SEG abstract, pp. 1

Cook NJ, Ciobanu CL, Meria D, Silcock D, Wade B (2013) Arsenopyrite-pyrite association in an orogenic gold ore: tracing mineralization history from textures and trace elements. Econ Geol 108(6):1273-1283. https://doi.org/10.2113/econgeo.108.6.1273

Davis WJ, Ryan JJ, Sandeman HA, Tella, S (2008) A Paleoprotorozoic detrital zircon age for a key conglomeratic horizon within the Rankin inlet area, Kivalliq region, Nunavut: implications for Archean and Proterozoic evolution of the area.Geological Survey of Canada, Current Research 2008-8, p 8

Dubé B, Gosselin P (2007) Greenstone-hosted quart-carbonate vein deposits. Geol Assoc Can Miner Depos Div Spec Pap 5:49-73

Dubé B, Mercier-Langevin P, Castonguay S, McNicoll VJ, Bleeker W, Lawley CJM, De Souza S, Jackson SE, Dupuis C, Gao J-F, Bécu V, Pilote P, Goutier J, Beakhouse GP, Yergeau D, Oswald W, Janvier V, Fontaine A, Pelletier M, Beauchamp AM, Katz LR, Kontak DJ, Tóth Z, Lafrance B, Gourcerol B, Thurston PC, Creaser RA, Enkin RJ, El Goumi N, Grunsky EC, Schneider DA, Kelly CJ, Lauzière K (2015) Precambrian lode gold deposits - a summary of TGI-4 contributions to the understanding of lode gold deposits, with an emphasis on implications for exploration. In: Dubé B, MercierLangevin P (ed) Targeted geoscience initiative 4: contributions to the understanding of Precambrian lode gold deposits and implications for exploration. Geol Survey Can, Open File 7852, pp 1-24
Folk RL (2005) Nano bacteria and the formation of framboidal pyrite: textural evidence. J Earth Syst Sci 114:369-374

Fougerouse D, Reddy SM, Saxey DW, Rickard WDA, van Riessen A, Micklethwaite S (2016) Nanoscale gold clusters in arsenopyrite controlled by growth rate not concentration: evidence from atom probe microscopy. Am Mineral 101(8):1916-1919. https://doi.org/10. 2138/am-2016-5781CCBYNCND

Frei R, Dahl PS, Duke EF, Hansen TR, Frandsson MM, Jensen LA (2008) Trace element and isotopic characterization of Neoarchean and Paleoproterozoic iron formations in the Black Hills (South Dakota USA): assessment of chemical change during 2.9-1.9 Ga deposition bracketing the 2.4-2.2 Ga first rise of atmospheric oxygen. Precambrian Res 162(3-4):441-474. https://doi.org/10.1016/j. precamres.2007.10.005

Fripp REP (1976) Stratabound gold deposits in Archean banded iron formation, Rhodesia. Econ Geol 71(1):58-75. https://doi.org/10. 2113/gsecongeo.71.1.58

Gao J-F, Jackson SE, Dubé B, Kontak DJ, De Souza S (2015) Genesis of the Canadian Malartic, Côté Gold, and Musselwhite gold deposits: insights from LA-ICP-MS element mapping of pyrite. In: Dubé B, MercierLangevin P (ed) Targeted geoscience initiative 4: contributions to the understanding of Precambrian lode gold deposits and implications for exploration. Geol Survey Can, Open File 7852, pp 157-175

Goldfarb RJ, Groves DI (2015) Orogenic gold: common or evolving fluid and metal sources through time. Lithos 233:2-26. https://doi.org/10. 1016/j.lithos.2015.07.011

Goldfarb RJ, Groves DI, Gardoll S (2001) Orogenic gold and geologic time: a global synthesis. Ore Geol Rev 18(1-2):1-75. https://doi.org/ 10.1016/S0169-1368(01)00016-6

Goldfarb RJ, Baker T, Dubé B, Groves DI, Hart CJR, Gosselin P (2005) Distribution, character and genesis of gold deposits in metamorphic terranes. In: Hedenquist JW, Thompson JFH, Goldfarb RJ, Richards JP (eds) Economic Geology, 100th Anniversary Volume 19052005, Society of Economic Geologists, Littleton, pp 407-450

Gourcerol B, Thurston PC, Kontak DJ, Côté-Mantha O (2015a) Interpretations and implications of preliminary LA ICP-MS analysis of chert for the origin of geochemical signatures in banded iron formations (BIFs) from the Meadowbank gold deposit, Western Churchill Province, Nunavut. Chem Geol 410:89-107. https://doi. org/10.1016/j.chemgeo.2015.06.008

Gourcerol B, Thurston PC, Kontak DJ, Côté-Mantha O, Biczok J (2015b) The geochemistry of chert from the banded iron formation-type Musselwhite and Meadowbank gold deposits: distinguishing primary and mineralization-related signatures of chert. Geol Survey Can, Current Res 2015-1, pp 24. https://doi.org/10.4095/295531

Gourcerol B, Thurston PC, Kontak DJ, Côté-Mantha O, Biczok J (2016a) Depositional setting of Algoma-type banded iron formation. Precambrian Res 281:47-79. https://doi.org/10.1016/j.precamres. 2016.04.019

Gourcerol B, Kontak DJ, Thurston PC, Petrus JA (2016b) Application of LA ICP-S of sulfides to the deconvolution of elemental paragenesis and associations in hydrothermal gold systems. Geol Soc of America, Denver, Program with Abstracts, v. 48, No. 7

Groves DI, Goldfarb RJ, Gebre-Mariam M, Hagemann SG, Robert F (1998) Orogenic gold deposits: a proposed classification in the context of their crustal distribution and relationship to other gold deposit types. Ore Geol Rev 13(1-5):7-27. https://doi.org/10.1016/S01691368(97)00012-7

Groves DI, Goldfarb RJ, Robert F, Hart CJR (2003) Gold deposits in metamorphic belts: overview of current understanding, outstanding problems, future research and exploration significance. Econ Geol 100:203-224

Hall RS, Rigg DM (1986) Geology of the West Anticline Zone, Musselwhite Prospect, Opapimiskan Lake, Ontario, Canada. In: Macdonald AJ (ed) Gold '86; an international symposium on the 
geology of gold deposits; proceedings volume. GOLD '86, Toronto, Ontario, pp 124-136

Howell D, Griffin WL, Pearson NJ, Powell W, Wieland P, O'Reilly SY (2013) Trace element portioning in mixed-habit diamonds. Chem Geol 355:134-143. https://doi.org/10.1016/j.chemgeo.2013.07.013

Hrabi RB, Barclay WA, Fleming D, Alexander RB (2003) Structural evolution of the Woodburn Lake group in the area of the Meadowbank gold deposit, Nunavut. Geological Survey of Canada Current Research 2003-C27, p 10

Janvier V (2016) Géologie du gisement d'or Meadowbank encaissé dans des formations de fer rubanées, Nunavut, Canada. $\mathrm{PhD}$ thesis, Québec, Université du Québec, Institut national de la recherche scientifique, pp. 504

Janvier V, Castonguay S, Mercier-Langevin P, Dubé B, McNicoll V, Pehrsson S, Malo M, De Chavigny B, Cote-Mantha, O, (2015) Preliminary results of geology of the Portage deposit, Meadowbank gold mine, Churchill Province, Nunavut, Canada. Geol Survey Can, Current Res 2015-2, pp. 18

Kelly CJ, Schneider DA (2015) Insights into the timing of mineralization and metamorphism in the North Caribou greenstone belt, western Superior Province. In: Dubé B, Mercier-Langevin P (eds) Targeted Geoscience Initiative 4: Contributions to the understanding of Precambrian lode gold deposits and implications for exploration. Geological Survey of Canada, Open File 7852, pp 245-253

Kerswill JA (1993) Models for iron-formation-hosted gold deposits. In: Kirkham RV, Sinclair WD, Thorpe RI, Duke JM (eds) Mineral deposit modelling. Geological Association of Canada Special Paper 40, pp 171-199

Kerswill JA (1996) Iron-formation stratabound gold. In: Eckstrand OR, Sinclair WD, Thorpe RI (ed) Chapter 15 of Geology of Canadian Mineral Deposit Types, Geological Survey of Canada, no. 8, pp 367382 (also Geological Society of America, The Geology of North America v. 1, P-1, pp. 367-382)

Kontak DJ (2015) Applications and implications of trace element chemistry and elemental mapping of ore minerals to hydrothermal ore deposit discrimination and genetic models. Geol Ass Can-Mineral Ass Can Joint Annual Meeting, May 3-7, Montreal, Quebec, Program with abstracts, vol 38, pp 293

Kontak DJ, Smith PK (1993) Ametaturbidite-hosted lode gold deposit: the Beaver Dam deposit Nova Scotia I. Vein paragenesis and mineral chemistry. Can Min 31:471-522

Kretschmar U, Scott SD (1976) Phase relations involving arsenopyrite in the system Fe-As-S and their application. Can Min 41:221-270

Large RR, Maslennikov VV, Robert F, Danyushevsky LV, Chang Z (2007) Multi-stage sedimentary and metamorphic origin of pyrite and gold in the Giant Sukhoi Log Deposit, Lena Gold Province, Russia. Econ Geol 102(7):1233-1267. https://doi.org/10.2113/ gsecongeo.102.7.1233

Large RR, Danyushevsky L, Hollit C, Maslennikov V, Meffre S, Gilbert S, Bull S, Scott R, Emsbo P, Thomas H, Singh B, Foster J (2009) Gold and trace element zonation in pyrite using a laser imaging technique: implications for the timing of gold in orogenic and Carlin-style sediment-hosted deposits. Econ Geol 104(5):635-668. https://doi.org/10.2113/gsecongeo.104.5.635

Large RR, Bull SW, Maslennikov VV (2011) A carbonaceous sedimentary source-rock model for Carlin-type and orogenic gold deposits. Econ Geol 106(3):331-358. https://doi.org/10.2113/econgeo.106.3.331

Large R, Thomas H, Craw D, Henne A, Henderson S (2012) Diagenetic pyrite as a source for metals in orogenic gold deposits, Otago Schist, New Zealand. N Z J Geol Geophys 55(2):137-149. https://doi.org/ 10.1080/00288306.2012.682282

Large RR, Halpin JA, Danyushevsky LV, Maslennikov VV, Bull SW, Long JA, Gregory DD, Lounejeva E, Lyons TW, Sack PJ, McGoldrock PJ, Calver CR (2014) Trace element content of sedimentary pyrite as a new proxy for deep-time ocean-atmosphere evolution. Earth Planet Sci Lett 389:209-220. https://doi.org/10. 1016/j.epsl.2013.12.020

Lawley CJM, Dubé B, Mercier- Langevin P, Kjarsgaard B, Knight R, Vaillancourt D (2015a) Defining and mapping hydrothermal footprints at the BIF-hosted Meliadine gold district, Nunavut, Canada. J Geochem Explor 155:33-55. https://doi.org/10.1016/j.gexplo.2015.04.001

Lawley CJM, Dubé B, Mercier-Langevin P, McNicoll VJ, Creaser RA, Pehrsson SJ, Castonguay S, Blais J-C, Simard M, Davis WJ, Jackson SE (2015b) Setting, age, and hydrothermal footprint of the emerging Meliadine gold district, Nunavut. In: Dubé B, Mercier-Langevin P (eds) Targeted Geoscience Initiative 4: Contributions to the Understanding of Precambrian Lode Gold Deposits and Implications for Exploration. Geological Survey of Canada, Open File 7852, pp 99-111

Lawley CJM, Creaser RA, Jackson S, Yang Z, Davis B, Pehrsson S, Dubé B, Mercier-Langevin P, Vaillancourt D (2015c) Unravelling the Western Churchill Province paleoproterozoic gold metallotect: constraints from $\mathrm{Re}-\mathrm{Os}$ arsenopyrite and $\mathrm{U}-\mathrm{Pb}$ xenotime geochronology and LA-ICP-MS arsenopyrite trace element chemistry at the BIFhosted Meliadine Gold District, Nunavut, Canada. Econ Geol 110(6):1425-1454. https://doi.org/10.2113/econgeo.110.6.1425

Lawley CJM, Jackson S, Zhaoping Y, Davis W, Eglington B (2017) Tracing the transition of gold from source to sponge to sink. Scientific communications. Econ Geol 112(1):169-183. https://doi. org/10.2113/econgeo.112.1.169

Longerich HP, Jackson SE, Günther D (1996) Inter-laboratory note. Laser ablation inductively coupled plasma mass spectrometric transient signal data acquisition and analyte concentration calculation. J Anal At Spectrom 11(9):899-904. https://doi.org/10.1039/ JA9961100899

McCuaig TC, Kerrich R (1994) HFSE/REE fractionations in high-MgO magmas as indicators of mantle source characteristics and melting depths. Program with Abstracts- Geol Ass Can-Miner Ass Can: Joint Annual Meeting, 19:73

McCuaig TC, Kerrich R (1998) P-T-t deformation-fluid characteristics of lode gold deposits: evidence from alteration systematics. Ore Geol Rev 12(6):381-453. https://doi.org/10.1016/S0169-1368(98) 00010-9

McNicoll V, Dubé B, Castonguay S, Oswald W, Biczok J, MercierLangevin P, Skulski T, Malo M (2016) The world-class Musselwhite BIF-hosted gold deposit, Superior Province Canada: new high-precision U-Pb geochronology and implications for the geological setting of the deposit and gold exploration. Precambrian Res 272:133-149. https://doi.org/10.1016/j.precamres.2015.09.029

Morelli RM, Bell CC, Creaser RA, Simonetti A (2010) Constraints on the genesis of gold mineralization at the Homestake gold deposit, Black Hills, South Dakota from rhenium-osmium sulfide geochronology. Mineral Deposita 45(5):461-480. https://doi.org/10.1007/s00126010-0284-9

Müller W, Shelley M, Miller P, Broude S (2009) Initial performance metrics of a new custom-designed ArF excimer LA-ICPMS system coupled to a two-volume laser-ablation cell. J Anal At Spectrom 24(2):209-214. https://doi.org/10.1039/B805995K

Neyedley K, Hanley JJ, Fayek M, Kontak DJ (2017) Textural, fluid inclusion, and stable oxygen isotope constraints on vein formation and gold precipitation at the 007 deposit, Rice Lake Greenstone Belt, Bissett, Manitoba, Canada. Econ Geol 112:628-660

Oswald W, Castonguay S, Dubé B, McNicoll VJ, Biczok J, Malo M, MercierLangevin P (2015) Geological setting of the world-class Musselwhite gold Mine, Superior Province, northwestern Ontario, and implications for exploration. In: Dubé B, Mercier-Langevin P (eds) Targeted Geoscience Initiative 4: Contributions to the Understanding of 1376 Precambrian Lode Gold Deposits and Implications for Exploration. Geological Survey of Canada, Open File 7852, pp 69-84

Paton C, Hellstrom J, Paul B, Woodhead J, Hergt J (2011) Iolite: freeware for the visualization and processing of mass spectrometric data. $\mathrm{J}$ 
Anal At Spectrom 26(12):2508-2518. https://doi.org/10.1039/ c1ja10172b

Pehrsson SJ, Wilkinson L, Zaleski E (2004) Geology of the Meadowbank gold deposit area, Nunavut. Geol Survey Can, Open File 4269, scale $1: 20000$

Pehrsson SJ, Berman RG, Davis WJ (2013) Paleoproterozoic orogenesis during Nuna aggregation: a case study of reworking of the Rae craton, Woodburn Lake, Nunavut. Precambrian Res 232:167-188. https://doi.org/10.1016/j.precamres.2013.02.010

Phillips GN, Powell R (2010) Formation of gold deposits: a metamorphic devolatilization model. J Metamorph Geol 28(6):689-718. https:// doi.org/10.1111/j.1525-1314.2010.00887.x

Phillips GN, Groves DN, Martyn JE (1984) An epigenetic origin for Archean banded iron formation-hosted gold deposits. Econ Geol 79(1):162-171. https://doi.org/10.2113/gsecongeo.79.1.162

Pitcairn IK, Teagle DAH, Craw D, Olivo GR, Kerrich R, Brewer TS (2006) Sources of metals and fluids in orogenic gold deposits: insights from the Otago and Alpine schists, New Zealand. Econ Geol 101(8):1525-1546. https://doi.org/10.2113/gsecongeo.101.8.1525

Pitcairn IK, Olivo GR, Teagle DAH, Craw D (2010) Sulfide evolution during prograde metamorphism of the Otago and Alpine Schists, New Zealand. Can Min 48(5):1267-1295. https://doi.org/10.3749/ canmin.48.5.1267

Poulsen KH, Robert F, Dubé B (2000) Geological classification of Canadian gold deposits. Geol Survey Can, Bulletin 540, pp. 106

Putnis A (2002) Mineral replacement reactions: from macroscopic observations to microscopic mechanisms. Mineral Mag 66(5):689-708. https://doi.org/10.1180/0026461026650056

Putnis A, Putnis CV (2010) The mechanism of re-equilibration of solids in the presence of a fluid phase. J Solid State Chem 180:1783-1786

Putnis CV, Geisler T, Schmid-Beurmann P, Stephan T, Giampaolo C (2007) An experimental study of the replacement of leucite by analcime. Am Mineral 92(1):19-26. https://doi.org/10.2138/am.2007.2249

Reich M, Kesler SE, Utsunomiya S, Palenik CS, Chryssoulis SL, Ewing RC (2005) Solubility of gold in arsenian pyrite. Geochim Cosmochim Acta 69(11):2781-2796. https://doi.org/10.1016/j.gca. 2005.01.011

Ridley JR, Diamond LW (2000) Fluid chemistry of orogenic lobe gold deposits and implications for genetic model. Rev Econ Geol 13: $141-162$

Rittner M, Müller W (2012) 2D mapping of LA-ICPMS trace element distributions using R. Comput Geosci 42:152-161. https://doi.org/ 10.1016/j.cageo.2011.07.016

Rollinson HR (1993) Using geochemical data: evaluation, presentation, interpretation. Longman Scientific and Technical, London, pp. 352

Schieber J (2002) Sedimentary pyrite: a window into the microbial past. Geology 30(6):531-534. https://doi.org/10.1130/0091-7613(2002) $030<0531$ :SPAWIT $>2.0 . \mathrm{CO} ; 2$

Scholz F, Neumann T (2007) Trace element diagenesis in pyrite-rich sediments of the Achterwasser lagoon, SW Baltic Sea. Mar Chem 107(4):516-532. https://doi.org/10.1016/j.marchem.2007.08.005

Scott RJ, Meffre S, Woodhead J, Gilbert SE, Berry RF, Emsbo P (2009) Development of framboidal pyrite during diagenesis low-grade regional metamorphism and hydrothermal alteration. Econ Geol 104(8):1143-1168. https://doi.org/10.2113/gsecongeo.104.8.1143

Sherlock RL, Alexander RB, March R, Barclay WA (2001a) Geologic setting of the Meadowbank iron formationhosted gold deposits. Geological Survey of Canada Current Research 2001-C11, pp. 23

Sherlock RL, Alexander RB, March R. Barclay WA (2001b) Geologic setting of the Meadowbank iron formation-hosted gold deposits. Geol Survey Can, Open File 3149, scale 1:10 000
Sherlock RL, Pehrsson MS, Logan AV, Hrabi RB, Davis WJ (2004) Geological setting of the Meadowbank Gold Deposits, Woodburn Lake Group, Nunavut. Explor Min Geol 13(1-4):67-107. https:// doi.org/10.2113/gsemg.13.1-4.67

Steadman JA, Large RR (2016) Synsedimentary, diagenetic, and metamorphic pyrite, pyrrhotite and marcasite at the Homestale BIF-hosted gold deposit, South Dakota, USA: insights on Au-As ore genesis from textural and LA-ICP-MS trace element studies. Econ Geol 111(7):17311752. https://doi.org/10.2113/econgeo.111.7.1731

Steadman JA, Large RR, Davidson GJ, Bull SW, Thompson J, Ireland TR, Holden P (2014) Paragenesis and composition of ore minerals in the Randalls BIF-hosted gold deposits, Yilgarn Craton, Western Australia: implications for the timing of deposit formation and constraints on gold sources. Precambrian Res 243:110-132. https://doi. org/10.1016/j.precamres.2014.01.002

Sylvester PC, Cabri LJ, Turbett MN, McMahon G, Laflamme JGH, Peregoedova A (2005) Synthesis and evaluation of a fused pyrrhotite standard reference material for platinum-group element and gold analyses by laser ablation-ICPMS. Geol Survey Finland, Espoo, Finland, 16-20, 10th International Platinum Symposium; Platinum-group elements; from genesis to beneficiation and environmental impact; extended abstracts

Tella S, Paul D, Berman RG, Davis WJ, Peterson TD, Pehrsson SJ, Kerswill JA (2007) Bedrock geology compilation and regional synthesis of parts of Hearne and Rae domains, western Churchill Province, Nunavut-Manitoba. Geol Survey Can, Open File 5441, scale 1:550 000

Thomas HV, Large RR, Bull SW, Maslennikov V, Berry RF, Fraser R, Froud S, Moye R (2011) Pyrite and pyrrhotite textures and composition in sediments, laminated quartz veins and reefs at Bendigo gold mine, Australia: insights for ore genesis. Econ Geol 106(1):1-31. https://doi.org/10.2113/econgeo.106.1.1

Thurston P, Kamber BS, Whitehouse M (2012) Archean cherts in banded iron formation: insight into Neoarchean ocean chemistry and depositional processes. Precambrian Res 214-215:227-257. https://doi. org/10.1016/j.precamres.2012.04.004

Tomkins AG (2010) Windows of metamorphic sulfur liberation in the crust: implication for gold deposit genesis. Geochim Cosmochim Acta 74(11):3246-3259. https://doi.org/10.1016/j.gca.2010.03.003

Tomkins AG, Pattison DRM, Zaleski E (2004) The Hemlo gold deposit, Ontario; an example of melting and mobilization of a precious metal-sulfosalt assemblage during amphibolite facies metamorphism and deformation. Econ Geol 99(6):1063-1084. https://doi. org/10.2113/gsecongeo.99.6.1063

Wagner T, Klemd R, Wenzel T, Mattson B (2007) Gold upgrading in metamorphosed massive sulfide ore deposits: direct evidence from laser-ablation-inductively coupled plasma-mass spectrometry analysis of invisible gold. Geology 35(9):775-778. https://doi.org/10. 1130/G23739A.1

Wohlgemuth-Ueberwasser CC, Jochum KP (2015) Capability of fs-LAICP-MS for sulfide analysis in comparison to ns-LA-ICP-MS: reduction of laser induced matrix effects? J Anal At Spectrom 30(12): 2469-2480. https://doi.org/10.1039/C5JA00251F

Woodhead J, Hellstrom J, Hergt J, Greig A, Maas R (2007) Isotopic and elemental imaging of geological materials by laser ablation Inductively Coupled Plasma mass spectrometry. J Geostand Geoanal Res 31:331-343

Wright GM (1967) Geology of the southeastern barren grounds, parts of the districts of Mackenzie and Keewatin. Geol Survey Can, Memoire 350, pp. 91 